\title{
Phytoplankton succession and nitrogen utilization during the development of an upwelling bloom
}

\author{
S. E. Fawcett*, B. B. Ward \\ Department of Geosciences, Princeton University, Princeton, New Jersey 08544, USA
}

\begin{abstract}
Diatoms typically constitute the majority of large phytoplankton in coastal systems, where they dominate upwelling conditions. The exact mechanism for diatom success has never been explicitly demonstrated, and we hypothesize that it is attributable to their early, rapid response to newly upwelled nitrate. This strategy allows diatoms to grow quickly and consume a disproportionate fraction of the available nutrients. To test this hypothesis and investigate differential growth of phytoplankton during the early stages of upwelling, an upwelling event - and the subsequent phytoplankton bloom - was simulated in a mesocosm experiment in Monterey Bay. Nitrate, ammonium and inorganic carbon uptake by 3 size fractions $(0.7-5 \mu \mathrm{m}, 5-20 \mu \mathrm{m},>20 \mu \mathrm{m})$ was measured daily through stable isotope tracer incubations. The particulate nitrogen and carbon biomass was initially dominated by the smallest phytoplankton, but the largest fraction increased most rapidly to dominate the biomass and nitrogen and carbon assimilation after a few days. All size fractions achieved similar maximum specific nitrate uptake rates $\left(\mathrm{V}_{\mathrm{NO} 3}\right)$, but this occurred most rapidly and was maintained longest by the largest fraction. This initial acceleration of $\mathrm{V}_{\mathrm{NO} 3}$ appears to be the mechanism by which diatoms exploit upwelling conditions. All size fractions assimilated carbon and nitrogen in a nearly constant ratio of $\sim 6.3$ as the assemblage returned to balanced growth. Pigment measurements and light microscopy independently documented changing phytoplankton abundance, with diatoms demonstrating a characteristic pattern of succession. Changes in diatom diversity and assemblage composition occurred early, providing evidence of a faster response than observable changes in nitrate or biomass implied.
\end{abstract}

KEY WORDS: Phytoplankton · Diatoms · Nitrate utilization · Upwelling simulation

\section{INTRODUCTION}

Primary production by marine phytoplankton is important to global cycles of both carbon (C) and nitrogen (N). Phytoplankton fix $\mathrm{CO}_{2}$ and assimilate inorganic nitrogen during photosynthesis and growth. Eventually, they either sink passively out of the surface ocean or are exported into the ocean interior as byproducts of grazing. This mechanism, the biological pump, results in the sequestration of organic $\mathrm{C}$ at depth and decreases surface ocean $p \mathrm{CO}_{2}$ (Volk \& Hoffert 1985). Biological pump efficiency depends on the fraction of $\mathrm{C}$ fixation that escapes recycling and is exported from the surface ocean. New production resulting in export of organic matter is supported by nitrate $\left(\mathrm{NO}_{3}{ }^{-}\right)$supplied to the system from depth (sensu Dugdale \& Goering 1967). The fraction of new produc- tion relative to total primary production is generally quantified by an f-ratio (Eppley \& Peterson 1979), where high f-ratios imply high $\mathrm{NO}_{3}{ }^{-}$dependence and high export production.

The most productive regions in the ocean are associated with eastern boundary currents where upwelling of cold, nutrient-rich waters from depth stimulates phytoplankton blooms (e.g. Dugdale 1985, Chavez et al. 1991, Probyn 1992). These upwelling regions comprise approximately $1 \%$ of the global ocean surface area (www.noaa.gov), but account for $>20 \%$ of the world's marine fish catch (Rykaczewski \& Checkley 2008) due to high biomass accumulation at lower trophic levels. Bloom-forming phytoplankton species are typically eukaryotic cells that are either large, protected from grazing, or both (Irigoien et al. 2004). Indeed, escape from grazing may explain the ultimate 
accumulation of high biomass during phytoplankton blooms. However, initial rapid exploitation of newly upwelled nutrients is required for any escape strategy to be successful, and many studies have shown that large phytoplankton thrive under conditions of elevated nutrients (Varela et al. 1991, Tamigneaux et al. 1995, Kudela \& Dugdale 1996).

Diatoms are the quintessential bloom-forming phytoplankton and are typically observed in high abundance in coastal and upwelling regions (Buck et al. 1992, Chavez \& Smith 1995, Chavez 1996). Photosynthesis by diatoms is thought to account for $25 \%$ of the 45 to $50 \mathrm{Gt}$ of organic $\mathrm{C}$ that is fixed annually in the oceans (Nelson et al. 1995), and their ability to grow rapidly in high nutrient environments makes diatoms the basis of the short and efficient food webs that support much of the world's fish catch (Jickells 1998). Diatoms range in size, but typically constitute the majority of the 'larger phytoplankton size fraction' in marine surface water communities. Their size may be in part responsible for their tendency to bloom in upwelling regions because higher levels of turbulence are required to prevent sinking (Huisman \& Sommeijer 2002). Size also determines susceptibility to grazing, and larger grazers tend to lag behind the rapidly accumulating diatom population at the beginning of a bloom due to their longer developmental cycles. Even when grazing pressure prevents the accumulation of biomass to bloom levels, diatoms have been observed to grow at sufficiently high rates to maintain a major contribution to the biomass (Goericke 2002).

Observations from both enclosure experiments (Joint et al. 2002, Samuelsson et al. 2002) and incubations of natural assemblages in seawater (Wetz \& Wheeler 2003) have identified diatoms as major primary producers in bloom conditions. In addition to successful escape from grazing, diatom dominance is likely due to their capacity to exploit upwelling conditions far more effectively than other phytoplankton. Malone (1980) first linked the success of large phytoplankton $(>20 \mu \mathrm{m})$ in upwelling regimes specifically to the use of $\mathrm{NO}_{3}{ }^{-}$, and it is thought that diatoms flourish in these regions because they are able to out-compete other phytoplankton for newly upwelled $\mathrm{NO}_{3}{ }^{-}$. While diatoms have been observed almost ubiquitously in high nutrient environments, it has not been explicitly demonstrated that their ability to grow more rapidly on $\mathrm{NO}_{3}{ }^{-}$is the reason for their success in upwelling regions. Dugdale \& Wilkerson (1991) investigated total phytoplankton assemblage specific nitrate uptake rates $\left(\mathrm{V}_{\mathrm{NO} 3}\right)$ in 3 high nutrient-low chlorophyll regions. They postulated that high community $\mathrm{V}_{\mathrm{NO} 3}$ was correlated with the presence of diatoms, and low community $\mathrm{V}_{\mathrm{NO} 3}$ occurred in regions lacking significant diatom populations. However, they were not able to unequivocally demonstrate that
$\mathrm{NO}_{3}{ }^{-}$assimilation by diatoms was responsible for the high community $\mathrm{V}_{\mathrm{NO} 3}$ observed.

The objective of the present study was to investigate the explicit link between $\mathrm{NO}_{3}{ }^{-}$assimilation and diatom dominance of upwelling regions. We hypothesized that the mechanism diatoms utilize to succeed in high nutrient environments may be to achieve maximum $\mathrm{V}_{\mathrm{NO} 3}$ more rapidly than other phytoplankton, and maintain this elevated rate until the available $\mathrm{NO}_{3}{ }^{-}$has been depleted. This strategy would allow diatoms to accumulate a high concentration of biomass early during upwelling that can then sustain the elevated $\mathrm{V}_{\mathrm{NO}}$ and assure diatoms a disproportionate share of the available nutrients. Initial rapid acceleration of $\mathrm{V}_{\mathrm{NO} 3}$ may also ensure that diatoms outpace their grazers to accumulate high levels of biomass. As a result, diatoms are the dominant phytoplankton in upwelling regions where they contribute disproportionately to primary production.

In order to test this hypothesis, an upwelling event was simulated in mesocosm experiments, and the progression of the resultant phytoplankton bloom was monitored. Changes in total community and sizefractionated phytoplankton biomass were measured, as well as rates of $\mathrm{NO}_{3}{ }^{-}$and ammonium $\left(\mathrm{NH}_{4}{ }^{+}\right)$assimilation and $\mathrm{CO}_{2}$ fixation, to quantify the contribution by different fractions of the phytoplankton community to $\mathrm{N}$ and $\mathrm{C}$ uptake. Photosynthetic pigment distributions allowed for an independent assessment of the phytoplankton functional groups constituting the photoautotrophic assemblage. Light microscopy was used to enumerate and identify the species present in order to investigate diversity and dominance by individual groups.

\section{MATERIALS AND METHODS}

Field experiment. A simulated upwelling experiment was carried out in Monterey Bay, California, in August 2006. Water was collected from a small boat using repeated casts with a 301 Niskin bottle in central Monterey Bay $\left(36^{\circ} 50.86^{\prime} \mathrm{N}, 121^{\circ} 57.88^{\prime} \mathrm{W}\right.$; water column depth = $250 \mathrm{~m}$ ). The water was collected from $70 \mathrm{~m}$ where the nitrate concentration ([ $\left.\mathrm{NO}_{3}^{-}\right]$) was sufficiently high to initiate a bloom. The depth was chosen on the basis of a quick determination of $\left[\mathrm{NO}_{3}{ }^{-}\right]$using a handheld spectrometer (Hach DR/820). Water was transported to the dock in acid-cleaned, seawater-rinsed 601 barrels, and used to fill 3 acid-cleaned, seawater-rinsed 2001 polyethylene barrels. The barrels (hereafter B1, B2 and B3) were incubated on the dock where surface water light and temperature conditions were simulated using plastic screens and running seawater baths. The experiment was conducted during an upwelling season to enhance 
the probability of sampling assemblages that were representative of Monterey Bay upwelling events. An inoculum of surface phytoplankton was supplied to each barrel by adding 21 of water collected from $2 \mathrm{~m}$ depth at the same station.

The barrels were mixed several times each day, and explicitly before sampling, by stirring with a clean PVC rod. Every day over the course of $7 \mathrm{~d}$ (Day 2 to Day 8), 6 clear polycarbonate bottles were filled with water (1.5 l) from each barrel, and tracers - $\mathrm{Na}^{15} \mathrm{NO}_{3}$, $\left({ }^{15} \mathrm{NH}_{4}\right)_{2} \mathrm{SO}_{4}$ and $\mathrm{NaH}^{13} \mathrm{CO}_{3}$ - were added separately to 2 incubation bottles from each barrel. $\mathrm{Na}^{15} \mathrm{NO}_{3}$ and $\mathrm{NaH}^{13} \mathrm{CO}_{3}$ were added at levels of ca. $10 \%$ of the ambient concentration ( $\left[\mathrm{NO}_{3}{ }^{-}\right]$in all 3 barrels was estimated daily using a handheld spectrometer in order to calibrate ${ }^{15} \mathrm{NO}_{3}{ }^{-}$tracer additions) and ${ }^{15} \mathrm{NH}_{4}{ }^{+}$additions were set at $100 \mathrm{nmol} \mathrm{l}^{-1}$. Bottles were returned to the seawater baths and incubated for $3 \mathrm{~h}$ under screens to ensure the same light levels as experienced by the barrels. Incubations were then filtered in parallel through $20 \mu \mathrm{m}$ and $5 \mu \mathrm{m}$ pore size polycarbonate filters, and all 3 size fractions (including the total unfractionated; $500 \mathrm{ml}$ each) were collected on pre-combusted $47 \mathrm{~mm}$ $\mathrm{GF} / \mathrm{F}$ filters. Filters were frozen and stored at $-80^{\circ} \mathrm{C}$ for later analysis in the laboratory. Similarly size fractionated samples (500 $\mathrm{ml}$ each) were collected and frozen for subsequent pigment analysis.

Measurement of DIN and DON concentrations. For each day of the experiment, $\left[\mathrm{NO}_{3}{ }^{-}\right]$was measured in the laboratory using a Teledyne Chemiluminescence NO/NOx Analyzer (Model 200E) (Garside 1982). Each sample was measured in triplicate, and standards were run after every 20 samples to correct for instrument drift. Nitrite concentrations $\left(\left[\mathrm{NO}_{2}^{-}\right]\right)$were determined colorimetrically (Strickland \& Parsons 1968), and absorbance was measured on a Varian 100 Bio UVVisible Spectrophotometer. Ammonium concentrations $\left(\left[\mathrm{NH}_{4}{ }^{+}\right]\right)$were measured according to the method of Koroleff (1983), and dissolved organic nitrogen (DON) concentrations were measured using the persulfate oxidation method of Bronk et al. (2000). Once converted to $\mathrm{NO}_{3}{ }^{-}$, concentrations of converted DON + ambient $\mathrm{NO}_{3}^{-}$were measured using a Teledyne Chemiluminescence NO/NOx Analyzer (Model 200E), and the ambient $\left[\mathrm{NO}_{3}^{-}\right],\left[\mathrm{NO}_{2}^{-}\right]$and $\left[\mathrm{NH}_{4}{ }^{+}\right]$for each sample was subtracted from the total to obtain the DON value.

Quantification of particulate $\mathrm{N}$, particulate $\mathrm{C}$ and rates of $\mathrm{NO}_{3}{ }^{-}, \mathbf{N H}_{4}{ }^{+}$and $\mathbf{C O}_{2}$ uptake. Frozen $\mathrm{GF} / \mathrm{F}$ filters were dried in a desiccating oven at $60^{\circ} \mathrm{C}$ for approximately $48 \mathrm{~h}$. In the laboratory, 2 sections of each filter were cut out, placed in tin boats, and pelletized to be measured on a Europa Scientific 20/20 triple collector mass spectrometer. Measurements were corrected for both the instrument blank, and a measured tin boat + filter blank, comprising a blank pre-combusted GF/F. ${ }^{15} \mathrm{~N}$ in particulate $\mathrm{N}(\mathrm{PN})$ and ${ }^{13} \mathrm{C}$ in particulate carbon (PC) were measured from separate replicate samples in order to evaluate the rate of $\mathrm{NO}_{3}{ }^{-}$and $\mathrm{NH}_{4}{ }^{+}$assimilation and $\mathrm{CO}_{2}$ fixation by the different phytoplankton size fractions. For each tracer, 2 replicates of every sample of each of the 3 size fractions filtered from all eighteen incubation bottles ( 6 per barrel) on each of the $7 \mathrm{~d}$ were measured. PC samples were not fumed with acid to remove excess inorganic carbon, and may thus slightly overestimate biomass $\mathrm{C}$ and underestimate $\mathrm{C}$-specific uptake rates. However, Kudela \& Dugdale (2000) compared PC samples from Monterey Bay treated with $0.5 \mathrm{ml}$ sulfurous acid with untreated PC samples and found no significant difference. Additionally, cell counts by light microscopy (described below) detected no coccolithophorids in the phytoplankton assemblage, and thus detected no significant source of inorganic $\mathrm{C}$.

Atom percent (At\%) and beam intensity data were measured by mass spectrometry for all samples (analytical precision $<0.2 \%$ ). Daily standard curves bracketing anticipated sample masses were run prior to samples, with urea as a standard for $\mathrm{N}$ and sucrose as a standard for $\mathrm{C}$ measurements. Using the daily standard curves, the mass of PN and PC in each sample was calculated. This resulted in PN and PC concentrations for all particles $>0.7 \mu \mathrm{m}$ (total community), for particles $0.7-20 \mu \mathrm{m}$, and for particles $0.7-5 \mu \mathrm{m}$. The $0.7-20 \mu \mathrm{m}$ values were subtracted from the total community measurement to give a value for all particles $>20 \mu \mathrm{m}$ (largest size fraction). Similarly, the 0.7-5 $\mu \mathrm{m}$ values (small size fraction) were subtracted from the $0.7-20 \mu \mathrm{m}$ measurement to give a value for all particles of 5-20 $\mu \mathrm{m}$ (middle size fraction). In addition to the measured PN and PC concentrations for the total community, the different size fractionated values were added together as an independent measure of total assemblage biomass (sum). In all cases, the error ( \pm 1 SD from the mean of replicate samples) was propagated using standard statistical practices.

Rates of PN and PC production were calculated (separately) for all phytoplankton size fractions in all barrels for each day of the experiment, according to the original equation of Dugdale \& Goering (1967):

$$
\begin{aligned}
\rho_{M}= & \left\{\left(\mathrm{PM}(\mu \mathrm{M})_{\text {size fraction }}\right) \times\left(\text { At } \%_{\text {size fraction }}\right)\right\} / \\
& \left\{\left(\mathrm{At} \%(\mathrm{M})_{\text {initial }}\right) \times(\text { time }(\mathrm{h}))\right\}
\end{aligned}
$$

where

$$
\begin{aligned}
\operatorname{At} \%(\mathrm{M})_{\text {initial }}= & \left([\mathrm{M}]_{\text {ambient }} \times(\text { Nat-abundance } \mathrm{M})+\right. \\
& {\left.[\mathrm{M}]_{\text {tracer }} \times(99)\right) /\left([\mathrm{M}]_{\text {initial }}\right) }
\end{aligned}
$$

and

$$
[\mathrm{M}]_{\text {initial }}=[\mathrm{M}]_{\text {ambient }}+[\mathrm{M}]_{\text {tracer }}
$$

$\mathrm{M}$ refers to the species of interest: $\mathrm{NO}_{3}{ }^{-}, \mathrm{NH}_{4}{ }^{+}$or $\mathrm{CO}_{2}$ $\left(\mu \mathrm{mol} \mathrm{l^{-1 }}\right) ; \rho_{\mathrm{M}}$ is the transport rate of the species of 
interest $\left(\mu \mathrm{mol} \mathrm{l}^{-1} \mathrm{~h}^{-1}\right)$; Nat-abundance $\mathrm{M}=0.365 \%$ for ${ }^{15} \mathrm{~N}$ and $1.07 \%$ for ${ }^{13} \mathrm{C}_{i}[\mathrm{M}]_{\text {ambient }}$ was measured daily for $\mathrm{NO}_{3}{ }^{-}$and $\mathrm{NH}_{4}{ }^{+}$, and taken to be $2000 \mu \mathrm{mol} \mathrm{l}{ }^{-1}$ for $\mathrm{CO}_{2}$. No correction was applied for possible isotope dilution due to remineralization of ${ }^{14} \mathrm{~N}-\mathrm{NH}_{4}{ }^{+}$during the ${ }^{15} \mathrm{~N}-\mathrm{NH}_{4}{ }^{+}$incubations. This potential experimental artifact is likely minimized by the short $(\sim 3 \mathrm{~h})$ incubations, but $\mathrm{NH}_{4}{ }^{+}$uptake rates should still be considered conservative estimates.

Ratios of $\rho_{\mathrm{CO} 2}$ to $\rho_{\mathrm{NO} 3}$ and $\rho_{\mathrm{CO} 2}$ to $\rho_{\mathrm{NH} 4}$ were computed for the total assemblage and the different size fractions by a linear regression of measured $\mathrm{NO}_{3}{ }^{-}$, $\mathrm{NH}_{4}{ }^{+}$and $\mathrm{CO}_{2}$ uptake rates.

Specific rates of uptake $\left(\mathrm{V}_{\mathrm{M}}\right)$ were calculated for $\mathrm{NO}_{3}{ }^{-}, \mathrm{NH}_{4}{ }^{+}$and $\mathrm{CO}_{2}$ by normalizing the transport rates $\left(\rho_{M}\right)$ to either $N$ or $C$ biomass (i.e. $V_{M}=\rho_{M} / P M$ ). Specific rates are expressed in units of $\mathrm{d}^{-1}$, scaled to the $12 \mathrm{~h}$ photoperiod for Monterey Bay in August 2006. Total and size-fractionated f-ratios were then calculated according to Eppley \& Peterson (1979): $\mathrm{f}=\mathrm{V}_{\mathrm{NO} 3} /$ $\left(\mathrm{V}_{\mathrm{NO} 3}+\mathrm{V}_{\mathrm{NH} 4}\right)$.

All results are reported as the mean of replicate experiments and/or measurements $\pm 1 \mathrm{SD}$, and the number of replicates is noted in the figure legends. For rate and f-ratio calculations, error was propagated according to standard statistical practices. All comparisons discussed are statistically significant (Student's $t$-test, $\mathrm{p} \leq 0.01$ ) unless otherwise noted.

Photosynthetic pigment analysis. Pigment samples from each time point were filtered in parallel $(500 \mathrm{ml}$ each) onto $47 \mathrm{~mm} \mathrm{GF/F} \mathrm{filters} \mathrm{to} \mathrm{obtain} \mathrm{size} \mathrm{fractions} \mathrm{as}$ described above for the incubations. Filters were immediately wrapped in foil, frozen on dry ice and stored in the dark at $-80^{\circ} \mathrm{C}$ until analysis. Concentrations of major ubiquitous (e.g. chlorophyll $a$, chlorophyll $c 2$ ) as well as diagnostic (e.g. fucoxanthin, peridinin) photosynthetic pigments were measured by HPLC at the University of North Carolina, Wilmington (Wright et al. 1991, Vidussi et al. 1996). The degradation product of chlorophyll $a$ is chlorophyllide $a$, which is sometimes produced as an extraction artifact during HPLC analysis of high biomass samples (Jeffrey \& Hallegraeff 1987). Chlorophyllide $a$ is a smaller molecule than chlorophyll $a$, and the retention time of this analyte in the chromatograph column resembles that of chlorophyll $c 2$. If this occurs, it is impossible to separate the contribution of chlorophyllide a from chlorophyll $c 2$, and HPLC analysis will indicate elevated concentrations of chlorophyll $c 2$. We suspect this may have occurred in a few high biomass samples from Days 7 and 8 in B3. Therefore, measured concentrations of chlorophyll $a$ and chlorophyll $c 2$ were added together and reported as chlorophyll ${ }^{*}$, and results are discussed in terms of this summed value.

Light microscopy and phytoplankton diversity. Phytoplankton functional groups and individual spe- cies were identified and counted in paraformaldehyde ( $1 \%$ ) preserved samples by light microscopy. Counts were made of cells large enough to be identified at the species level (settled), as well as of smaller cells distinguishable at the genus or taxon level (filtered) (Garrison et al. 2005). Seven major functional groups were identified, and the number of species counted within each group ranged from 3 to 52 . Cell counts were normalized to cells $\mathrm{l}^{-1}$.

Shannon diversity indices $\left(H^{\prime}\right)$ were separately calculated for both the total phytoplankton community ( 7 functional groups) and for the diatom functional group (52 species) using the Vegan package included in the statistical freeware program R (Oksanen et al. 2008); http://vegan.r-forge.r-project.org/). $H^{\prime}$ indices for the 3 barrels were averaged for each day of the experiment.

\section{RESULTS}

\section{DIN, total PN and total PC}

The initial $\left[\mathrm{NO}_{3}{ }^{-}\right]$on Day 1 of the experiment averaged $21.7 \pm 1.1 \mu \mathrm{mol} \mathrm{l} \mathrm{l}^{-1}$, which represented the $\left[\mathrm{NO}_{3}{ }^{-}\right]$ at $70 \mathrm{~m}$ in Monterey Bay during August 2006. Between Days 1 and 4, $\left[\mathrm{NO}_{3}{ }^{-}\right]$in the barrels hardly changed, after which it began to decrease fairly rapidly as $\mathrm{NO}_{3}^{-}$was incorporated into phytoplankton biomass

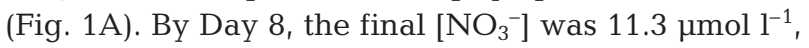
$11.8 \mathrm{~mol} \mathrm{l}^{-1}$, and $0.7 \mu \mathrm{mol} \mathrm{l^{-1 }}$ in B1, B2 and B3, respectively. By the end of the experiment the phytoplankton in B3 had exhausted the nutrient supply, while the community in B1 and B2 lagged by a day or two. B3 thus represents the most complete phytoplankton response to the simulated upwelling event, and B3 results will be presented in most detail here, although the same data were collected for all 3 barrels.

Initially, $\left[\mathrm{NH}_{4}{ }^{+}\right]$was $1.2 \pm 0.7 \mu \mathrm{mol} \mathrm{l}{ }^{-1}$ in $\mathrm{B} 1,1.0 \pm$ $0.6 \mu \mathrm{mol} \mathrm{l}^{-1}$ in B2 and $0.7 \pm 0.4 \mu \mathrm{mol} \mathrm{l}^{-1}$ in B3, consistent with seawater upwelled from $70 \mathrm{~m}$, before decreasing to nanomolar levels by Day 4 or 5 . The $\left[\mathrm{NH}_{4}{ }^{+}\right]$in B2 and B3 appeared to increase slightly on Days 7 and 8, possibly due to a small amount of micrograzer activity.

The PN biomass was very low in all mesocosms (1.0 \pm $0.07 \mu \mathrm{mol} \mathrm{l} \mathrm{l}^{-1} \mathrm{~N}$ ) until Day 4, when it began to increase. By the end of the experiment, the PN measured $12.7 \pm$ $1.8 \mu \mathrm{mol} \mathrm{l}^{-1} \mathrm{~N}$ in B1, $9.7 \pm 0.9 \mu \mathrm{mol} \mathrm{l^{-1 }} \mathrm{N}$ in B2, and $19.0 \pm 1.3 \mu \mathrm{mol} \mathrm{l}^{-1} \mathrm{~N}$ in B3 (Fig. 1A). This increase in PN mirrored the drawdown of $\mathrm{NO}_{3}{ }^{-}$, and in all 3 barrels, conservation of $\mathrm{N}$ mass was observed (i.e. a decrease in $\left[\mathrm{NO}_{3}{ }^{-}\right]$was paired with a similar sized increase in $\mathrm{PN}$ ). Concentrations of $\mathrm{NO}_{2}^{-}$were negligible throughout the experiment, and DON concentrations remained essentially constant at $\sim 3 \mu \mathrm{mol} \mathrm{l}^{-1}$, corroborating a robust $\mathrm{N}$ mass balance in all barrels (Table 1). 

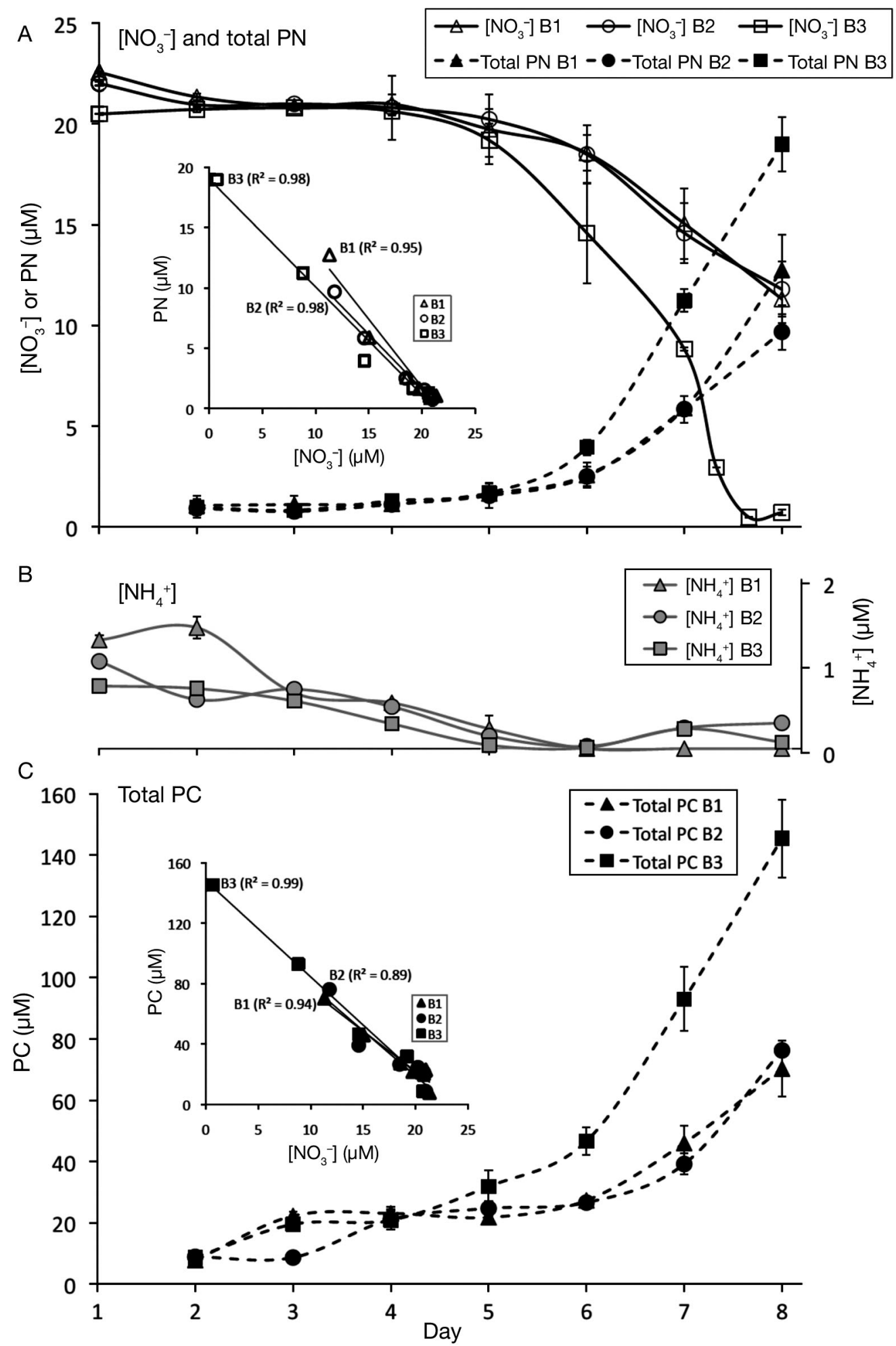

Fig. 1. (A) Drawdown of nitrate $\left(\mathrm{NO}_{3}^{-}\right.$) and accumulation of particulate nitrogen (PN) biomass by the total phytoplankton community in all barrels over the course of the experiment. Inset shows change in $\mathrm{PN}$ as a function of $\mathrm{NO}_{3}{ }^{-}$concentration ([NO$\left.\left.{ }_{3}^{-}\right]\right)$. (B) Ammonium concentration $\left(\left[\mathrm{NH}_{4}{ }^{+}\right]\right)$in all barrels over the time-course of the experiment. (C) Accumulation of particulate carbon (PC) biomass in all barrels as a function of time. Inset shows change in PC as a function of $\left[\mathrm{NO}_{3}{ }^{-}\right] . \mathrm{n}=3$ for $\left[\mathrm{NO}_{3}{ }^{-}\right] ; \mathrm{n}=8$ for $\mathrm{PN}_{i} \mathrm{n}=4$ for $\mathrm{PC}$, and where error bars are not visible, the error $( \pm 1 \mathrm{SD})$ was smaller than the size of the marker. For $\mathrm{NH}_{4}{ }^{+}$ measurements $\mathrm{n}=2$, with markers indicating the average value and the error bars the range of the measurements 
A similar pattern was observed in PC biomass accumulation (Fig. 1B). Initially, the PC concentration was $7.8 \pm$ $0.2 \mu \mathrm{mol} \mathrm{l}^{-1} \mathrm{C}$ in B1, $8.9 \pm 1.2 \mu \mathrm{mol} \mathrm{l}^{-1} \mathrm{C}$ in $\mathrm{B} 2$, and $8.7 \pm 0.4 \mu \mathrm{mol} \mathrm{l^{-1 }} \mathrm{C}$ in $\mathrm{B} 3$. While the PN increased only $\sim 10 \%$ between Days 2 and 3, the PC increased by $\sim 60 \%$ before plateauing at Day 4 in B3 and Day 5 in B1 and B2. By the end of the experiment, the PC concentration was twice as high in B3 as in B1 and B2, in keeping with the trend observed in both $\mathrm{NO}_{3}^{-}$drawdown and $\mathrm{PN}$ accumulation.

\section{Size-fractionated PN and PC measurements}

PN and PC increased for each size fraction of the phytoplankton assemblage over the time-course (results for B3 presented in Fig. 2A,B). Similar trends were observed in B1 and B2 (data not shown) although the maximum biomass accumulated was lower. At the beginning of the experiment, the smallest size fraction of the phytoplankton assemblage $(<5 \mu \mathrm{m})$ accounted for the largest percentage of both the $\mathrm{PN}$ and the PC (Fig. 2A,B insets). While all 3 size fractions increased in absolute concentration over the course of the simulated
Table 1. Data for $\mathrm{N}$ mass balance in the barrels for each day of the experiment (mean $\pm 1 \mathrm{SD}$ ). $\Sigma \mathrm{N}_{\text {species }}$ is the sum of $\mathrm{NO}_{3}{ }^{-}, \mathrm{NH}_{4}{ }^{+}$, dissolved organic nitrogen $(\mathrm{DON})$ and particulate nitrogen $(\mathrm{PN})$, where $\mathrm{PN}$ is the measured total community value. PN was below detection on Day 1 in all barrels. Nitrite concentrations were below detection for all samples and are thus not included here

\begin{tabular}{|c|c|c|c|c|c|}
\hline Day & $\begin{array}{c}{\left[\mathrm{NO}_{3}^{-}\right]} \\
\left.(\mu \mathrm{mol} \mathrm{l}]^{-1}\right)\end{array}$ & $\begin{array}{c}{\left[\mathrm{NH}_{4}^{+}\right]} \\
\left(\mu \mathrm{mol} \mathrm{l}^{-1}\right)\end{array}$ & $\begin{array}{c}\text { DON } \\
\left(\mu \mathrm{mol} \mathrm{l}^{-1}\right)\end{array}$ & $\begin{array}{c}\text { PN } \\
\left(\mu \mathrm{mol} \mathrm{l}^{-1}\right)\end{array}$ & $\begin{array}{c}\Sigma \mathrm{N}_{\text {species }} \\
\left(\mu \mathrm{mol} \mathrm{l}^{-1}\right)\end{array}$ \\
\hline \multicolumn{6}{|l|}{ Barrel 1} \\
\hline 1 & $22.6 \pm 0.03$ & $1.24 \pm 0.71$ & $3.2 \pm 0.1$ & & $27.0 \pm 0.72$ \\
\hline 2 & $21.3 \pm 0.14$ & $1.39 \pm 0.80$ & $3.1 \pm 0.2$ & $1.06 \pm 0.50$ & $26.9 \pm 0.97$ \\
\hline 3 & $20.9 \pm 0.16$ & $0.64 \pm 0.37$ & $3.2 \pm 0.1$ & $1.11 \pm 0.46$ & $25.9 \pm 0.62$ \\
\hline 4 & $20.9 \pm 0.47$ & $0.52 \pm 0.30$ & $3.1 \pm 0.3$ & $1.14 \pm 0.22$ & $25.7 \pm 0.67$ \\
\hline 5 & $19.7 \pm 1.72$ & $0.23 \pm 0.20$ & $3.0 \pm 0.2$ & $1.66 \pm 0.16$ & $24.6 \pm 1.75$ \\
\hline 6 & $18.6 \pm 0.88$ & $0.00 \pm 0.10$ & $3.1 \pm 0.2$ & $2.57 \pm 0.62$ & $24.3 \pm 1.10$ \\
\hline 7 & $15.0 \pm 1.75$ & $0.00 \pm 0.10$ & $3.4 \pm 0.3$ & $5.89 \pm 0.26$ & $24.3 \pm 1.80$ \\
\hline 8 & $11.3 \pm 1.20$ & $0.00 \pm 0.04$ & $3.2 \pm 0.1$ & $12.74 \pm 1.75$ & $27.2 \pm 2.12$ \\
\hline \multicolumn{5}{|c|}{ Average $\Sigma N_{\text {species }}$} & $25.7 \pm 1.24$ \\
\hline \multicolumn{6}{|c|}{ (a) } \\
\hline 1 & $22.0 \pm 0.11$ & $0.99 \pm 0.57$ & $3.1 \pm 0.2$ & & $26.1 \pm 0.61$ \\
\hline 2 & $21.0 \pm 0.17$ & $0.56 \pm 0.32$ & $3.0 \pm 0.4$ & $0.92 \pm 0.47$ & $25.5 \pm 0.72$ \\
\hline 3 & $21.0 \pm 0.19$ & $0.68 \pm 0.39$ & $3.2 \pm 0.1$ & $0.77 \pm 0.25$ & $25.7 \pm 0.51$ \\
\hline 4 & $20.8 \pm 1.6$ & $0.48 \pm 0.28$ & $3.2 \pm 0.2$ & $1.11 \pm 0.27$ & $25.6 \pm 1.66$ \\
\hline 5 & $20.2 \pm 0.53$ & $0.15 \pm 0.09$ & $3.3 \pm 0.2$ & $1.55 \pm 0.62$ & $25.2 \pm 0.84$ \\
\hline 6 & $18.5 \pm 1.45$ & $0.03 \pm 0.03$ & $3.2 \pm 0.1$ & \pm 0.49 & 24.2 \\
\hline 7 & $14.6 \pm 1.50$ & $0.24 \pm 0.16$ & $3.2 \pm 0.3$ & $5.84 \pm 0.67$ & $23.9 \pm 1.68$ \\
\hline 8 & $11.8 \pm 1.36$ & $0.29 \pm 0.17$ & $3.1 \pm 0.2$ & $9.68 \pm 0.89$ & $24.9 \pm 1.65$ \\
\hline \multicolumn{5}{|c|}{ Average $\Sigma \mathbf{N}_{\text {species }}$} & $25.1 \pm 1.15$ \\
\hline \multicolumn{6}{|l|}{ Barrel 3} \\
\hline 1 & $20.5 \pm 0.05$ & $0.72 \pm 0.41$ & $3.1 \pm 0.3$ & & $24.3 \pm 0.51$ \\
\hline 2 & $20.7 \pm 0.13$ & $0.69 \pm 0.40$ & $2.9 \pm 0.2$ & $0.98 \pm 0.23$ & $25.6 \pm 0.52$ \\
\hline 3 & $20.8 \pm 0.10$ & $0.55 \pm 0.31$ & $3.2 \pm 0.3$ & $0.83 \pm 0.24$ & $25.4 \pm 0.50$ \\
\hline 4 & $20.6 \pm 0.21$ & $0.28 \pm 0.17$ & $3.2 \pm 0.2$ & $1.29 \pm 0.27$ & $25.4 \pm 0.43$ \\
\hline 5 & $19.2 \pm 0.83$ & $0.04 \pm 0.02$ & $3.0 \pm 0.1$ & $1.68 \pm 0.46$ & $23.9 \pm 0.95$ \\
\hline 6 & $14.6 \pm 2.49$ & $0.01 \pm 0.02$ & $3.2 \pm 0.4$ & $4.95 \pm 0.38$ & $22.8 \pm 2.55$ \\
\hline 7 & $8.8 \pm 0.08$ & $0.23 \pm 0.13$ & $3.1 \pm 0.2$ & $11.22 \pm 0.57$ & $23.4 \pm 0.62$ \\
\hline \multirow[t]{2}{*}{8} & $0.7 \pm 0.15$ & $0.07 \pm 0.04$ & $3.2 \pm 0.2$ & $19.00 \pm 1.34$ & $23.0 \pm 1.37$ \\
\hline & \multicolumn{4}{|r|}{ Average $\Sigma \mathbf{N}_{\text {species }}$} & $24.2 \pm 1.08$ \\
\hline
\end{tabular}
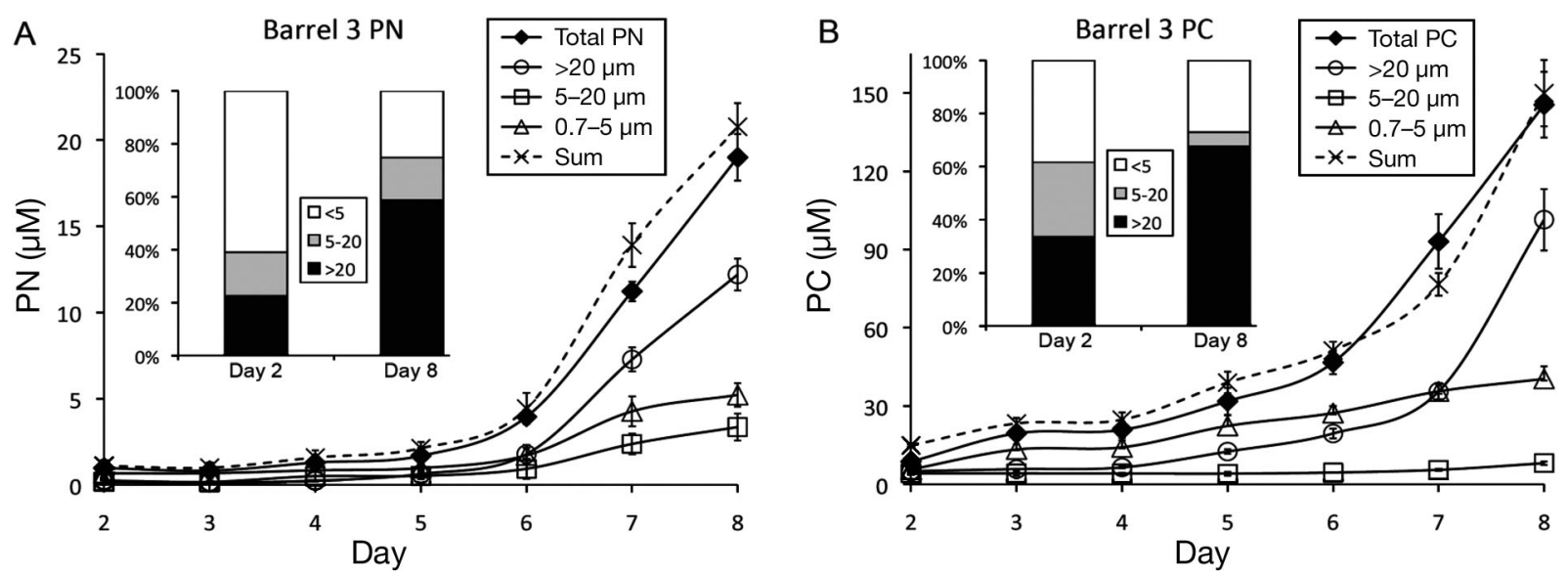

Fig. 2. Contribution of the different size fractions of the phytoplankton assemblage to (A) PN and (B) PC accumulation in B3 over the course of the experiment. The dashed black line labeled 'Sum' represents total phytoplankton biomass accumulation calculated as the addition of the contributions of the various size fractions: $\mathrm{n}=8$ for $\mathrm{PN} ; \mathrm{n}=4$ for PC, and error $( \pm 1 \mathrm{SD})$ was propagated for the calculated size fractions. Where error bars are not visible, the error was smaller than the size of the marker. Insets show the relative contribution (\%) of the different phytoplankton size-fractions to total PN and PC biomass on Day 2 and Day 8 (max. error $= \pm 8 \%$ ). Differences in biomass contributions on Day 2 vs. Day 8 were statistically significant for the $>20 \mu \mathrm{m}$ and $<5 \mu \mathrm{m}$ size fractions (student $t$-test, $\mathrm{p} \leq 0.01, \mathrm{n}=4$ for all samples) 
upwelling event (Fig. 2A,B), by Day 8 the largest size fraction dominated the biomass. The relative contribution of this $>20 \mu \mathrm{m}$ fraction increased almost 3-fold to $59 \%$ of the PN and $68 \%$ of the PC, while the $<5 \mu \mathrm{m}$ contribution decreased to $25 \%$ and $27 \%$ of the PN and PC, respectively. These changes were statistically significant (Student's $t$-test, $\mathrm{p} \leq 0.01$ ). The middle size fraction showed little change in its small relative contribution to the biomass over the course of the experiment.

\section{Size fractionated rates of $\mathrm{NO}_{3}{ }^{-}, \mathrm{NH}_{4}{ }^{+}$and $\mathrm{CO}_{2}$ uptake}

Total community assimilation of $\mathrm{NO}_{3}^{-}\left(\rho_{\mathrm{NO} 3}\right)$ and $\mathrm{NH}_{4}{ }^{+}\left(\rho_{\mathrm{NH} 4}\right)$ into $\mathrm{PN}$, fixation of $\mathrm{CO}_{2}\left(\rho_{\mathrm{CO} 2}\right)$ into PC for all the barrels, and uptake by the different size fractions in B3, are shown in Fig. 3A-F. In all the barrels, the smallest size fraction of the phytoplankton community initially took up $\mathrm{NO}_{3}{ }^{-}$the fastest, but rates in all fractions were slow until Day 4 (Fig. 3A). Over the course of the experiment, $\rho_{\mathrm{NO} 3}$ increased for all size fractions, with the largest phytoplankton cells displaying the fastest uptake rate by the end of the experiment (Fig. 3D). The maximum $\rho_{\mathrm{NO} 3}$ attained by the total assemblage in $\mathrm{B} 3$ was $0.5 \mu \mathrm{mol} \mathrm{l} \mathrm{l}^{-1} \mathrm{NO}_{3}{ }^{-} \mathrm{h}^{-1}$.

The relative contribution of the largest phytoplankton size fraction to $\mathrm{NO}_{3}{ }^{-}$assimilation in $\mathrm{B} 3$ increased 3-fold between Day 2 and 8, from approx. 20 to $60 \%$, whereas that of the $<5 \mu \mathrm{m}$ size fraction decreased by $\sim 30 \%$ (Fig. 3D inset). These changes were statistically significant (Student's $t$-test, $\mathrm{p} \leq 0.01$ ), whereas the 5-20 $\mu \mathrm{m}$ size fraction contribution varied least over the course of this experiment, and the change in its relative $\rho_{\mathrm{NO} 3}$ between Day 2 and 8 was not significant.

The uptake of $\mathrm{NH}_{4}{ }^{+}$followed the same general trends as that of $\mathrm{NO}_{3}{ }^{-}$, i.e. $\rho_{\mathrm{NH} 4}$ for all size fractions increased as the experiment progressed, with the relative contribution of the large fraction increasing most (Fig. 3B). The $<5 \mu \mathrm{m}$ size fraction initially dominated assimilation in all 3 barrels, as illustrated by the size-fractionated comparison for B3 (Fig. 3E). All the size fractions in B3 reached their maximum $\rho_{\mathrm{NH} 4}$ on Day 7 of the experiment rather than Day 8, as was the case for B1 and B2.

The relative contribution of the smallest phytoplankton cells to $\rho_{\mathrm{NH} 4}$ in B3 changed from approximately $50 \%$ on Day 2 to $15 \%$ on Day 8, concomitant with an increase in the largest size fraction contribution from approx. 40 to $60 \%$ (Fig. 3E inset). This trend of changing dominance was similar in B2 (Student's $t$-test, $\mathrm{p} \leq$ 0.01). Conversely, the relative contribution of the various size fractions in B1 hardly changed over the course of the experiment, and by Day 8 the $<5 \mu$ m cells continued to assimilate the same proportion of $\mathrm{NH}_{4}{ }^{+}$as they had done on Day 2 ( $60 \%$; data not shown).
$\mathrm{C}$ uptake rates increased with time in all 3 barrels (Fig. 3C). As with the accumulation of PN and PC (Fig. $1 \mathrm{~A}, \mathrm{~B}$ ), as well as $\rho_{\mathrm{NO} 3}$ and $\rho_{\mathrm{NH} 4}$, B3 displayed consistently higher values for $\mathrm{CO}_{2}$ assimilation than $\mathrm{B} 1$ and B2. Initially, the contributions of all 3 phytoplankton size fractions to $\rho_{\mathrm{CO} 2}$ in $\mathrm{B} 3$ (Fig. 3F) were similar (33 $\pm 5 \%$ ), but by Day 8 , the largest fraction completely dominated $\mathrm{C}$ assimilation and accounted for approximately $80 \%$ of $\mathrm{C}$ uptake. The relative contribution of the $<5 \mu \mathrm{m}$ cells decreased to $\sim 20 \%$, and the middle size fraction contribution was almost negligible $(<3 \%)$. In B1 and B2, the smallest size fraction made the largest contribution to $\rho_{\mathrm{CO} 2}$ at the beginning of the time course ( $50 \pm 9 \%$; data not shown), but the largest size fraction dominated $\mathrm{C}$ assimilation by the end of the experiment (50 $\pm 12 \%$; data not shown).

\section{Specific rates of $\mathrm{NO}_{3}{ }^{-}, \mathrm{NH}_{4}{ }^{+}$and $\mathrm{CO}_{2}$ uptake}

For biomass specific uptake rates $\left(\mathrm{V}_{\mathrm{NO} 3}, \mathrm{~V}_{\mathrm{NH} 4}\right.$ and $\left.\mathrm{V}_{\mathrm{CO} 2}\right), \rho_{\mathrm{NO} 3}$ and $\rho_{\mathrm{NH} 4}$ were normalized to $\mathrm{PN}$, and $\rho_{\mathrm{CO} 2}$ to PC. $\mathrm{V}_{\mathrm{NO} 3}$ was similar for all 3 barrels (Fig. 4A), and comparable to $\mathrm{V}_{\mathrm{CO} 2}$ (Fig. $4 \mathrm{C}, \mathrm{D}, \mathrm{F}$ ). These specific uptake rates imply a doubling time for the community of less than a day during the period of fastest growth. This is supported by an observed doubling of phytoplankton biomass in terms of PN and PC accumulation in less than a day during the later days of the experiment (Fig. 1A). While the concentration of $\mathrm{NO}_{3}{ }^{-}$tracer added was scaled each day to $\leq 10 \%$ of the ambient $\left[\mathrm{NO}_{3}{ }^{-}\right], \mathrm{V}_{\mathrm{NO} 3}$ may be overestimated at the very end of the experiment as ambient $\mathrm{NO}_{3}{ }^{-}$became extremely depleted in B3. The specific rates of $\mathrm{NH}_{4}{ }^{+}$uptake were considerably higher and more variable than those of $\mathrm{CO}_{2}$ and $\mathrm{NO}_{3}{ }^{-}$(Fig. 4B \& E), although $\mathrm{V}_{\mathrm{NH} 4}$ in $\mathrm{B} 3$ was approximately equal to $\mathrm{V}_{\mathrm{NO} 3}$ towards the end of the time-course. While all the phytoplankton size fractions in $\mathrm{B} 3$ achieved similar maximum $\mathrm{V}_{\mathrm{NO} 3}\left(\sim 1.2 \mathrm{~d}^{-1}\right.$; Fig. 4D), the $>20 \mu \mathrm{m}$ size fraction attained its maximum $\mathrm{V}_{\mathrm{NO} 3}$ by Day 3, earlier than the other fractions, and maintained this elevated rate until Day 7 , longer than the other fractions. The highest $\mathrm{V}_{\mathrm{NH} 4}$ and $\mathrm{V}_{\mathrm{CO} 2}$ attained in B3 were in the $>20 \mu \mathrm{m}$ and the $5-20 \mu \mathrm{m}$ fractions, respectively (Fig. 4E-F).

\section{C:N ratios}

The total community biomass C:N ratio on Day 2 was roughly 10:1 in all 3 barrels, higher than the predicted Redfield ratio of approximately 6.63:1 (Redfield et al. 1963) (Fig. 5A). On Day 3, these ratios increased in B1 and B3 to $\sim 20$ and 23 , respectively, and then gradually decreased to 5.5 in $\mathrm{B} 1$ and 7.7 in B3. The initial C:N in 

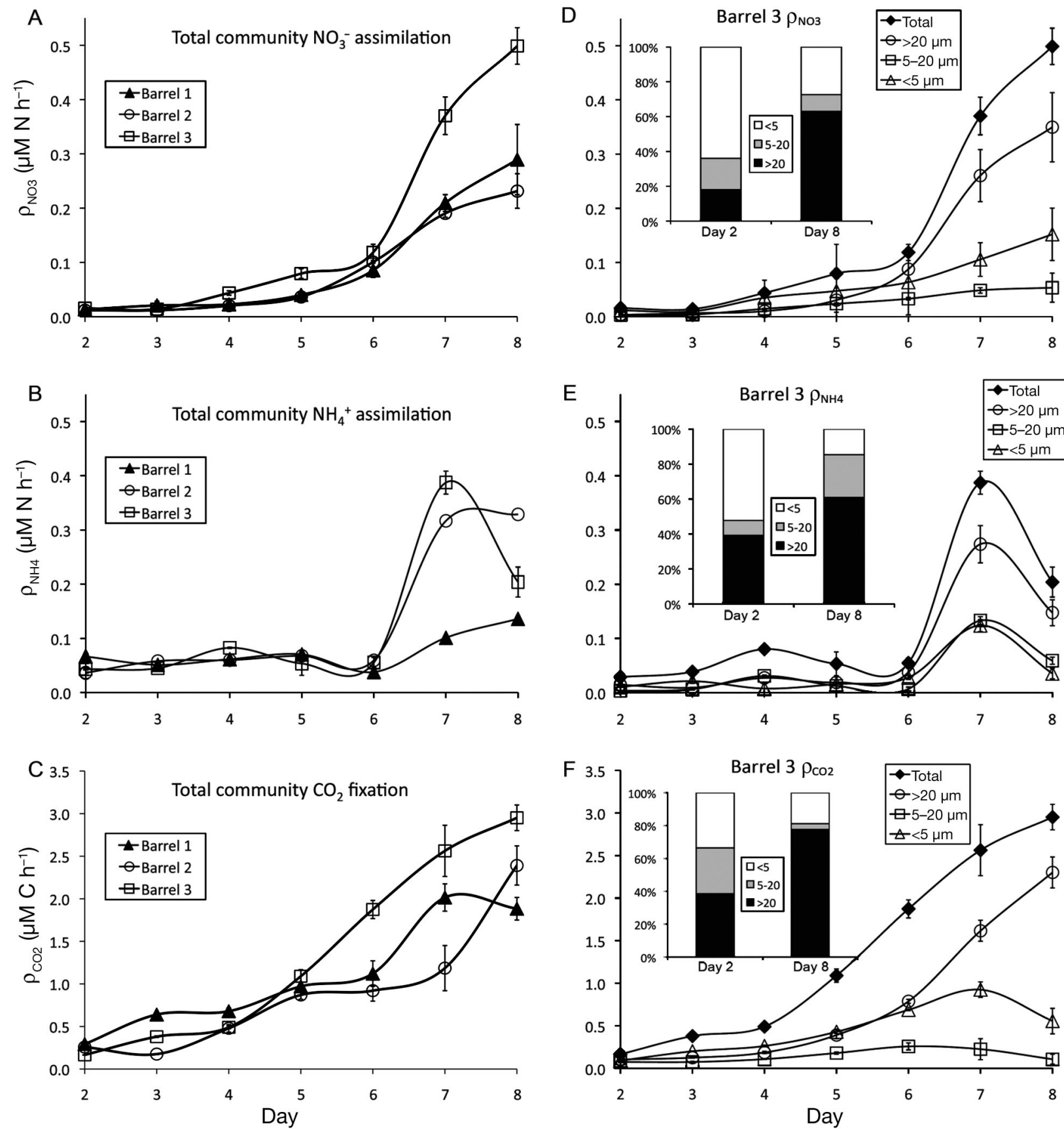

Fig. 3. Total phytoplankton assemblage uptake rates $\left(\rho, \mu \mathrm{mol} \mathrm{l}^{-1} \mathrm{~h}^{-1}\right)$ of (A) nitrate; (B) ammonium and (C) carbon in all barrels over the course of the experiment. Size fractionated rates of assimilation of (D) nitrate, (E) ammonium and (F) carbon for B3 as a function of time are also shown. Error $( \pm 1 \mathrm{SD})$ was propagated for the calculated size fractions $(\mathrm{n}=4$ for all samples). Where error bars are not visible, the error was smaller than the size of the marker. Insets show the relative contribution (\%) of the different phytoplankton size fractions to assimilation on Day 2 and Day 8 (max. error $= \pm 10 \%$ ). The difference between the contribution to $\mathrm{NO}_{3}{ }^{-}, \mathrm{NH}_{4}{ }^{+}$and $\mathrm{CO}_{2}$ uptake on Day 2 vs. Day 8 was statistically significant for all size fractions (Student $t$-test, $\mathrm{p} \leq 0.01, \mathrm{n}=4$ for all samples) except the $5-20 \mu \mathrm{m}$ fraction in (D) inset

B2 remained low until Day 3, after which it decreased to 7.7 by Day 8 .

Temporal patterns of individual size fraction $C: N$ were similar to the total community (Fig. 5B-D), although there were some notable differences. In all barrels, the largest size fraction had a considerably higher initial $C: N$ than the mean total assemblage $C: N$ until Day 4 (Day 5 in the case of B2), after which the ratio gradually decreased to values slightly higher than the Redfield ratio (Fig. 5B). The 5-20 $\mu \mathrm{m}$ size fraction 

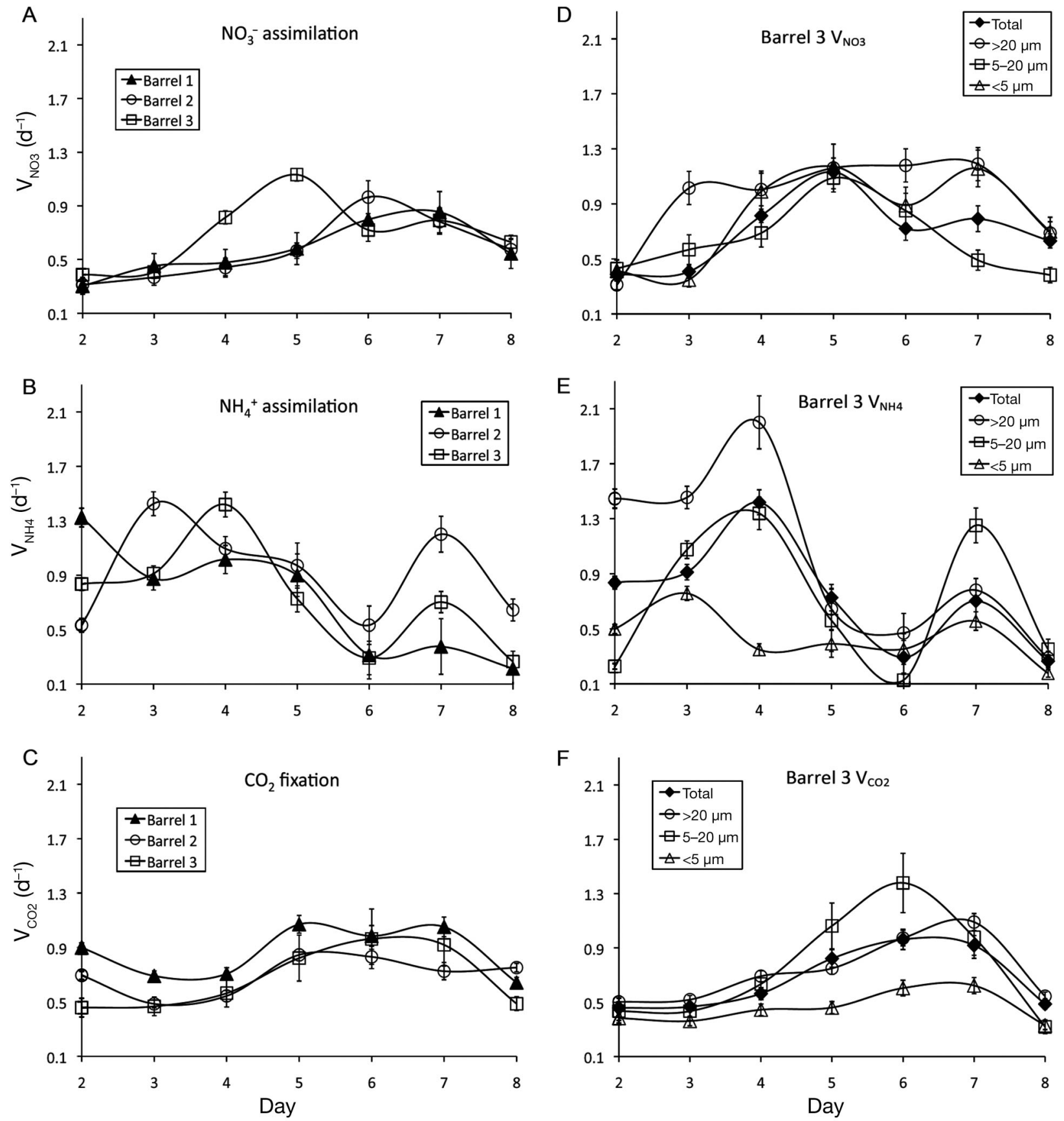

Fig. 4. Specific rates of assimilation $\left(\mathrm{V} \mathrm{h}^{-1}\right)$ of $(\mathrm{A})$ nitrate, $(\mathrm{B})$ ammonium and (C) carbon in all barrels for the total phytoplankton assemblage over the course of the experiment. Size-fractionated specific uptake rates of (D) nitrate, (E) ammonium and (F) carbon in B3 over time; $\mathrm{n}=4$ for all samples, and error ( $\pm 1 \mathrm{SD})$ was propagated for the calculated size fractions

also had a high C:N until approx. Day 4 (Fig. 5C), when the ratio declined to somewhat lower values than Redfield C:N. The smallest size fraction behaved most like the total assemblage (Fig. 5D).

Despite the large variability in $\mathrm{C}: \mathrm{N}$ of the phytoplankton biomass, a regression of $\mathrm{C}$ and $\mathrm{N}\left(\mathrm{NO}_{3}^{-}\right.$and $\mathrm{NH}_{4}{ }^{+}$) uptake rates $\left(\rho ; \mu \mathrm{mol} \mathrm{l}^{-1} \mathrm{~h}^{-1}\right)$ for the total phytoplankton assemblage for all days of the experiment indicates that $\mathrm{C}$ and $\mathrm{N}$ were assimilated in a fairly constant ratio of $6.3 \pm 1.2: 1\left(\mathrm{R}^{2}=0.8 ;\right.$ Fig. $\left.6 \mathrm{~A}\right)$. The summed average $\mathrm{C}: \mathrm{N}$ uptake ratio for the total community, calculated by a regression of $\rho_{\mathrm{C}}$ and $\rho_{\mathrm{N}}$ for all the different size fractions together, was $6.3 \pm 1.3: 1\left(R^{2}=0.75\right.$; Fig. 6A). The $>20 \mu \mathrm{m}$ fraction assimilated $\mathrm{C}$ and $\mathrm{N}$ in a ratio of $6.1 \pm 1: 1\left(\mathrm{R}^{2}=0.91\right.$; Fig. $\left.6 \mathrm{~B}\right)$, the $5-20 \mu \mathrm{m}$ fraction in a ratio of $6.3 \pm 1.4: 1\left(\mathrm{R}^{2}=0.56 ;\right.$ Fig. $\left.6 \mathrm{C}\right)$, and the 

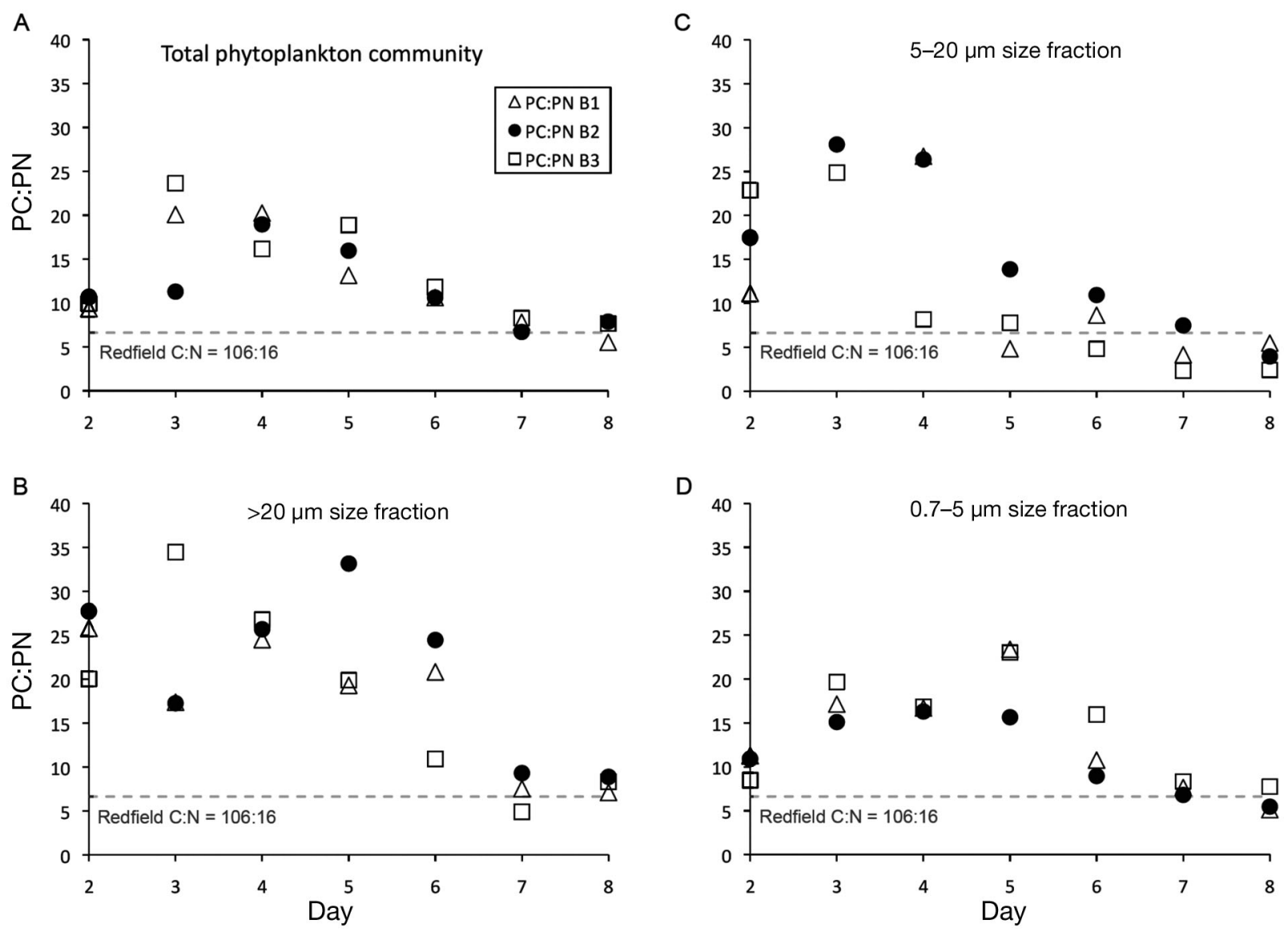

Fig. 5. Changing $\mathrm{C}: \mathrm{N}$ ratio as a function of time for (A) the total phytoplankton assemblage, (B) the $>20 \mu \mathrm{m}$ phytoplankton size fraction, (C) the 5-20 $\mu \mathrm{m}$ phytoplankton size fraction and (D) the $<5 \mu \mathrm{m}$ phytoplankton size fraction in all barrels (B1, B2 and B3). The dashed grey line in all panels indicates the Redfield C:N ratio predicted for phytoplankton elemental composition (6.63:1; Redfield et al. 1963). Values shown are averages ( $n=8$ for all samples); error $( \pm 1 \mathrm{SD})$ was propagated and max. error $= \pm 12 \%$

$<5 \mu \mathrm{m}$ fraction in a ratio of $5.7 \pm 1.3: 1\left(\mathrm{R}^{2}=0.67\right.$ Fig. 6D). For the middle and smallest size fractions, removing the B3 data that appeared to drive the high end of the $\rho_{\mathrm{C}}: \rho_{\mathrm{N}}$ relationship had almost no impact on the assimilation ratio $(<5 \%$ difference). It did however result in an improved linear fit, with $\mathrm{R}^{2}$ increasing to 0.88 for the $5-20 \mu \mathrm{m}$ fraction and 0.71 for the $<5 \mu \mathrm{m}$ fraction ( $\mathrm{p} \leq 0.01$ for all regressions).

\section{f-ratios}

Because $\mathrm{N}$ mass balance was observed in all barrels (Table 1), which implies that the source of all $\mathrm{N}$ was known, f-ratios were calculated as $\mathrm{V}_{\mathrm{NO} 3} /\left(\mathrm{V}_{\mathrm{NO} 3}+\mathrm{V}_{\mathrm{NH} 4}\right)$ (Eppley \& Peterson 1979). All the barrels behaved similarly, with total community f-ratios increasing from $0.29 \pm 0.09$ on Day 2 to $0.63 \pm 0.14$ on Day 8 (Fig. 7). The average f-ratio for all barrels and size fractions over the duration of the experiment was $0.46 \pm$ 0.18 .

\section{Pigment analysis}

The total community pigment concentrations were first detectable on Day 3, and increased from then on to the end of the experiment in all 3 barrels. The acceleration between Days 4 and 5 in B3 (Fig. 8A) coincided with the biomass increase measured as PN and PC (Figs. 1A \& 2A). Pigment concentrations in B1 and B2 increased slowly until Days 6 to 8 (data not shown), in keeping with delayed bloom development in these 2 barrels relative to $\mathrm{B} 3$.

The concentration of chlorophyll* (summed chlorophylls $a$ and $c 2$ ) was far higher than any other pigment in all barrels for all size fractions. It increased to $48 \mu \mathrm{g}$ $\mathrm{l}^{-1}$ by Day 8 in B3, and $39 \mu \mathrm{g} \mathrm{l}^{-1}$ of this was attributable to the $>20 \mu \mathrm{m}$ fraction (Fig. 8B). The $5-20 \mu \mathrm{m}$ and $<5 \mu \mathrm{m}$ fractions contributed $3.6 \mu \mathrm{g} \mathrm{l}^{-1}$ and $4.9 \mu \mathrm{g} \mathrm{l}^{-1}$ to chlorophyll ${ }^{*}$, respectively.

Size fractionated measurements revealed a large contribution of fucoxanthin (up to $7 \mathrm{\mu g} \mathrm{l}^{-1}$ ) from the $>20 \mu \mathrm{m}$ phytoplankton in B3 (Fig. 8B), indicative of a 

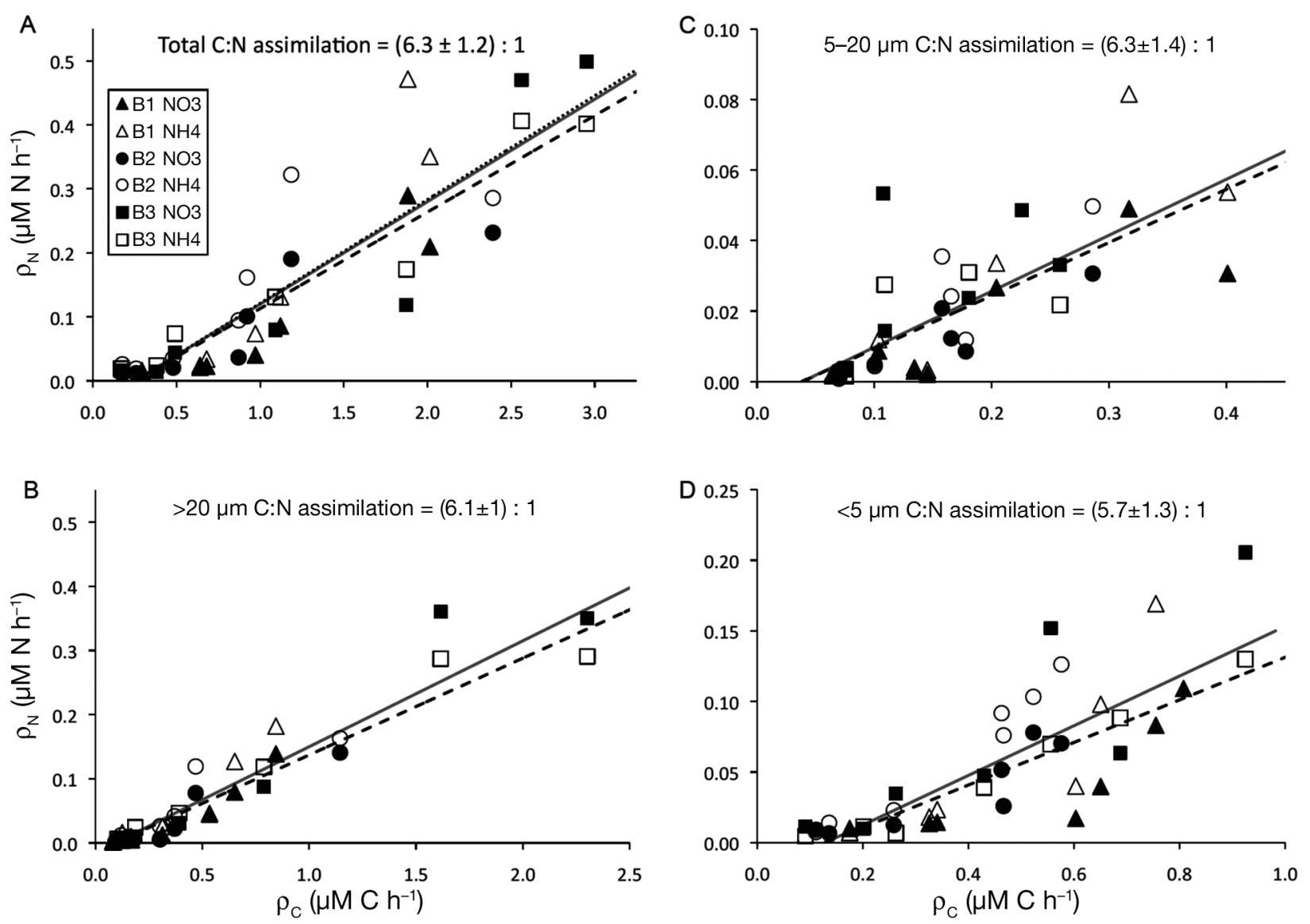

Fig. 6. Rate of nitrate $\left(\rho_{\mathrm{NO} 3}\right)$ and ammonium $\left(\rho_{\mathrm{NH} 4}\right)$ uptake as a function of carbon uptake $\left(\rho_{\mathrm{C}}\right)$ in all barrels for $(A)$ the total phytoplankton assemblage, (B) the $>20 \mu \mathrm{m}$ phytoplankton size fraction, (C) the $5-20 \mu \mathrm{m}$ phytoplankton size fraction and (D) the $<5 \mu \mathrm{m}$ phytoplankton size fraction. Note scale changes. In all panels, the solid line indicates the measured ratio of assimilation of $C$ and $N\left(\rho_{C}: \rho_{N}\right)$, and this value is marked on the plot. The dashed black line represents the predicted Redfield ratio of $\mathrm{C}$ and $\mathrm{N}$ assimilation by phytoplankton (6.63:1; Redfield et al. 1963). In (A) the dotted line shows the ratio of C:N uptake calculated from all measured size-fractionated transport rates in all barrels. Markers represent averages ( $\mathrm{n}=4$ for all samples); error $( \pm 1 \mathrm{SD})$ was propagated and max. error $= \pm 17 \%$. The stated ratio of $\rho_{\mathrm{C}}: \rho_{\mathrm{N}}$ for each size fraction represents the mean slope of the regression $(n=42) \pm 1 \mathrm{SD}$

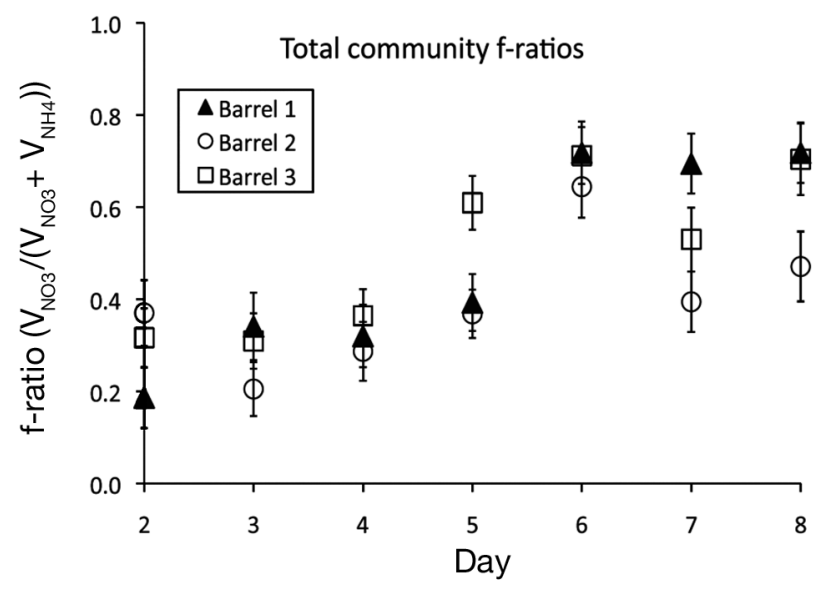

Fig. 7. Average f-ratios for the total phytoplankton assemblage in all barrels over the course of the experiment; $n=4$ for all samples, and error $( \pm 1 \mathrm{SD})$ was propagated high abundance of diatoms within this size fraction (Stauber \& Jeffrey 1988, Bjørnland \& Liaaen-Jensen 1989). There was also a notable fucoxanthin concentration associated with the $<5 \mu \mathrm{m}$ cells $\left(2.2 \mu \mathrm{g} \mathrm{l^{-1 }}\right.$; Fig. 8D), indicative of the presence of small diatoms or haptophytes (coccolithophorids). The middle size fraction contributed least (Fig. 8C), with a maximum fucoxanthin concentration $<1.6 \mu \mathrm{g} \mathrm{l^{-1 }}$. This observation is in keeping with the modest contribution of the 5-20 $\mu \mathrm{m}$ phytoplankton to biomass and $\mathrm{N}$ uptake (Figs. 2A,B \& 3B,D,F).

Peridinin, a pigment diagnostic for dinoflagellates (Hofmann et al. 1996), was significant only in the $>20 \mu \mathrm{m}$ size fraction in B3. Low concentrations of peridinin were also detected in the largest phytoplankton size fraction in B1 and B2, but not in the smaller fractions (data not shown). Thus, the peridinin concentration measured for the total assemblage can be 


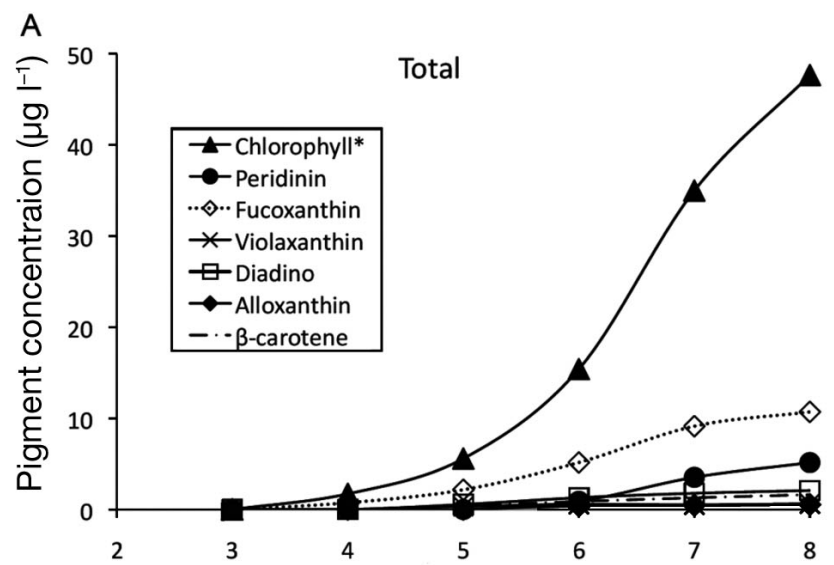

C
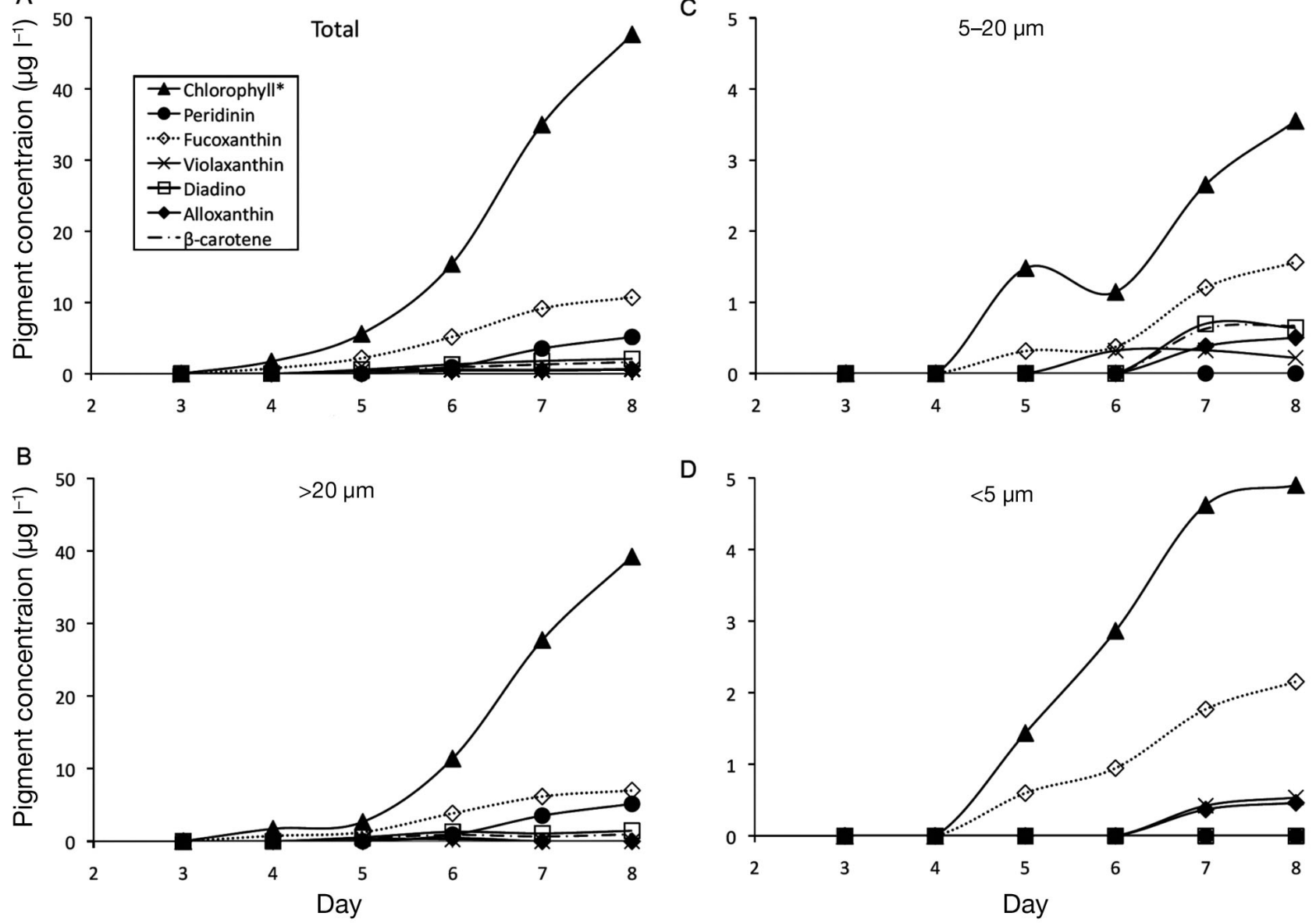

D

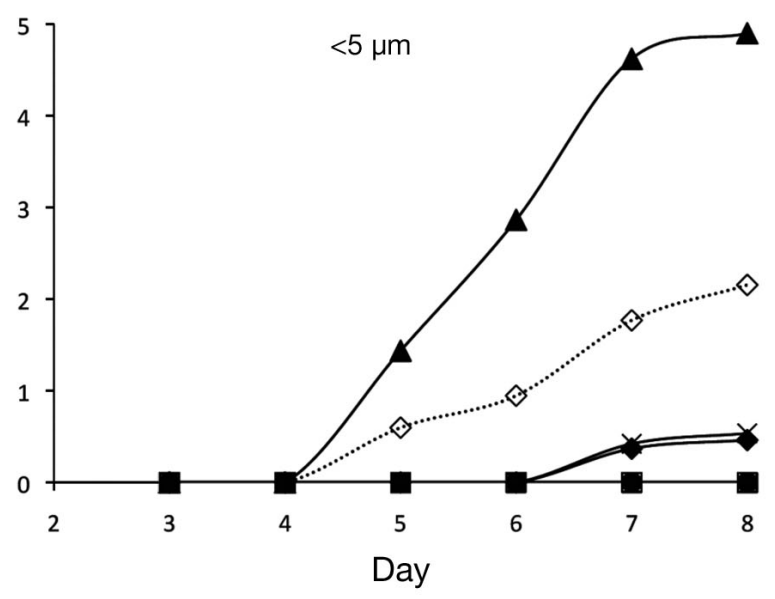

Fig. 8. Concentrations of ubiquitous (e.g. chlorophyll*) and diagnostic (e.g. fucoxanthin) pigments in B3 as a function of time for (A) the total phytoplankton assemblage, (B) the $>20 \mu \mathrm{m}$ phytoplankton size fraction, (C) the 5-20 $\mu$ m phytoplankton size fraction and (D) the $<5 \mu \mathrm{m}$ phytoplankton size fraction. Note scale changes

attributed solely to the largest phytoplankton size fraction, and all dinoflagellates must have been larger than $20 \mu \mathrm{m}$.

\section{Phytoplankton community composition and diversity}

Photosynthetic pigment analysis confirmed not only the presence of diatoms in the mesocosms, but their considerable abundance as well. However, there are other functional groups without diagnostic pigments that may also have contributed significantly to the community. Seven major phytoplankton groups (containing over 100 species) were identified by light microscopy: diatoms, dinoflagellates, ciliates, foraminifera, radiolarians, flagellates, and chlorophytes. Within these groups, the number of species counted ranged from 3 (chlorophytes) to 52 (diatoms). No haptophytes were detected by this method.
Based on the microscopy cell counts, Shannon diversity indices $\left(H^{\prime}\right)$ for the total phytoplankton community (Fig. 9A, top) revealed a general trend of increasing diversity over the course of the experiment, reaching a maximum on Day 8. Within the diatom group (Fig. 9A, bottom), diversity was initially low (Day 2), but it quickly increased (Day 3), even before much increase was obvious in the PN and PC biomass (Fig. 1A,B). Diatom diversity remained high until Day 5, and then decreased over the remainder of the experiment, while diversity of the total phytoplankton assemblage continued to increase.

Within the diatom assemblage, clear differences in temporal patterns occurred among species. At the beginning of the experiment, Pseudonitzschia spp. (probably several different species that cannot be distinguished microscopically; Stehr et al. 2002) contributed 50, 16 and $54 \%$ to the diatom assemblage in B1, B2 and B3, respectively, and diversity was low (Fig. 9B). By Day 8, Pseudonitzschia spp. abundance 

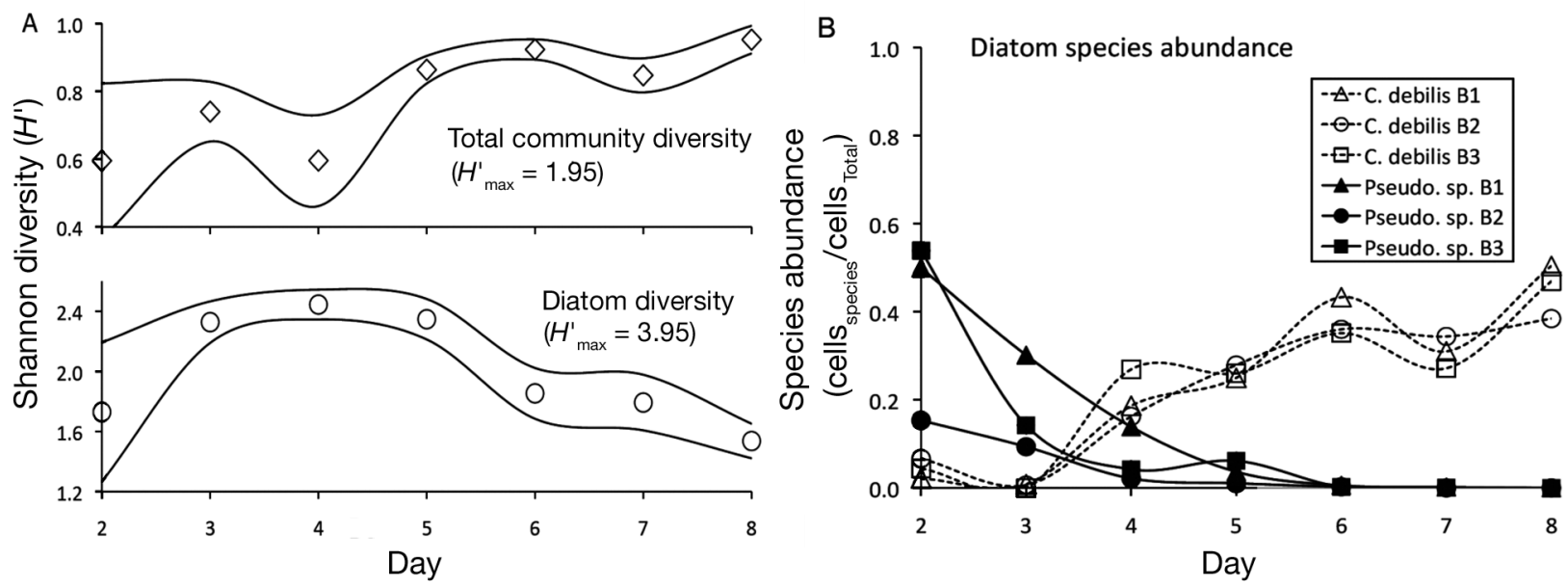

Fig. 9. (A) Diversity of the total phytoplankton community (top panel) and the diatom functional group (bottom panel) over the course of the experiment from microscopy cell counts as quantified by the Shannon diversity index $\left(H^{\prime}\right)$. Open diamonds and circles represent the average diversity in the 3 barrels for the total assemblage and diatom functional group, respectively. Solid black lines indicate variability about the mean $( \pm 1 \mathrm{SD})$, and are intended to represent an 'envelope' of changing diversity as a function of time. (B) Variations in the relative abundance of Pseudonitzschia spp. (Pseudo, a ubiquitous diatom) and Chaetoceros debilis (an upwelling diatom species) in all 3 barrels over the course of the experiment. Abundances are quantified as the number of cells counted for the species of interest normalized to the total cell count for each day of the experiment

had declined to $0.02,0.03$ and $0.02 \%$. Concomitant with this decline was an increase in diversity, which reached a maximum on Day 5 as the relative contribution of Chaetoceros debilis, an upwelling diatom (Round et al. 1990, Wetz \& Wheeler 2003), increased. The contribution of this species changed from 2 to $50 \%$ in B1, 7 to $38 \%$ in B2, and 5 to $47 \%$ in B3 by Day 8 when diversity was once again low. All abundance changes were significant (Student's $t$-test, $\mathrm{p} \leq 0.01$ ). Eleven different species of Chaetoceros were enumerated in B3, all of which increased in abundance around Day 4 and together accounted for $\sim 80 \%$ of the diatom cells by Day 8 of the experiment.

\section{DISCUSSION}

The measured $\left[\mathrm{NO}_{3}{ }^{-}\right]$in seawater used to fill the barrels was consistent with previous measurements of waters upwelled in Monterey Bay (Wilkerson et al. 2000), as well as with other regions demonstrating coastal divergence (e.g. Probyn 1985, Wilkerson et al. 1987, Toon et al. 2000). The barrels were inoculated with a small volume of surface seawater containing phytoplankton that had not been exposed to a strong upwelling event for the 2 wk preceding this study (www.pfeg.noaa.gov). Thus, the initial conditions in the barrels and the resulting community dynamics can be considered representative of a coastal phytoplankton assemblage exposed to newly upwelled $\mathrm{NO}_{3}{ }^{-}$after a considerable period of nutrient depletion (Chavez \& Smith 1995).

\section{$\mathrm{NO}_{3}{ }^{-}, \mathrm{NH}_{4}{ }^{+}$and $\mathrm{CO}_{2}$ assimilation}

Conservation of $\mathrm{N}$ mass between $\mathrm{NO}_{3}{ }^{-}$and $\mathrm{PN}$ was observed in all 3 barrels, although if the experiment had continued for longer, DON may have accumulated in the mesocosms (Bronk \& Ward 1999, Ward \& Bronk 2001, Wetz \& Wheeler 2003). However, we did not observe the end of the phytoplankton bloom in any of the barrels, as PN and PC were still increasing upon termination of the experiment. It is likely that the bloom would have ended almost immediately in B3, and within a day or two in B1 and B2 as the remaining nutrients were consumed.

All 3 phytoplankton size fractions increased in biomass over the course of the experiment, although the relative increase was much greater for the largest fraction $(>20 \mu \mathrm{m})$. The success of the largest phytoplankton in this study is indicative of their potential to exploit upwelling conditions. These results are consistent with previous studies showing that large phytoplankton can outcompete smaller autotrophs for resources during a bloom (e.g. Probyn 1985, Wilkerson et al. 2000, Wetz \& Wheeler 2003). Indeed, a recent analysis of several geographical datasets of phytoplankton diversity and abundance (Irigoien et al. 2004) confirmed previous observations that large phytoplankton usually dominate the algal assemblage at high biomass levels.

Part of the hypothesis central to this study was that larger phytoplankton, particularly diatoms, are able to dominate in upwelling conditions because they respond rapidly and early to the presence of $\mathrm{NO}_{3}{ }^{-}$. 
Measured specific growth rates and rates of uptake for the various size fractions support this hypothesis. By Day 6 of the experiment, the $>20 \mu \mathrm{m}$ cells in B3 had succeeded the $<5 \mu \mathrm{m}$ cells to dominate $\mathrm{NO}_{3}{ }^{-}, \mathrm{NH}_{4}{ }^{+}$and $\mathrm{CO}_{2}$ assimilation. The same trend was observed in B1 and B2, with the exception of ammonium uptake in B1, which was dominated by the smallest phytoplankton throughout the course of the experiment (data not shown). Given the affinity of small phytoplankton for reduced N (Probyn 1985, Dortch 1990, Owens et al. 1991), dominance of ammonium uptake by the smallest size-fraction should perhaps have been expected in all 3 barrels. We postulate that the absolute dominance of the community by large phytoplankton cells, particularly in B3, allowed them to out-compete the smaller cells for all nutrients by the end of the experiment. This ability to exploit new nutrients so rapidly partially explains the success of larger photoautotrophs in upwelling environments.

The absence of significant grazing in the barrels probably also contributed to the success of the larger phytoplankton fraction. A few small grazers were detected in the microscope counts, but the manner and depth of the original sampling likely excluded grazers capable of consuming larger cells. Even if grazers were initially present in small numbers or in juvenile stages, the length of the barrel experiment was insufficient to allow for the growth of grazers able to feed on larger phytoplankton. An examination of microscope counts of one of the only micrograzers present, Strombidium sp., showed a doubling of cell number between Day 2 and Day 8 in B3. Over the same time period however, the total biomass increased 20 -fold. In addition, there was no measureable accumulation of DON, consistent with minimal grazing in the barrels. Thus, the patterns we observed that substantiate the successful initial exploitation of $\mathrm{NO}_{3}{ }^{-}$by large cells are valid for the barrels and for the early stages of upwelling-initiated blooms in the ocean. The eventual growth of grazers in the ocean, however, guarantees that blooms are short-lived, and that biomass accumulations are rapidly removed.

\section{Specific rates of uptake}

While all phytoplankton size fractions eventually attained similar maximum specific rates of $\mathrm{NO}_{3}{ }^{-}$assimilation $\left(\mathrm{V}_{\mathrm{NO}}\right)$, the $>20 \mu \mathrm{m}$ phytoplankton responded most rapidly. By Day 3, these larger cells had achieved their maximum $\mathrm{V}_{\mathrm{NO} 3}$, and they maintained this rate longer than any other size fraction, until the available $\mathrm{NO}_{3}{ }^{-}$became depleted. This observation is consistent with the findings of Stolte \& Riegman (1995) that large phytoplankton cells are capable of taking up $\mathrm{NO}_{3}{ }^{-}$at a maximum rate for longer than small cells. This strategy appears to be the mechanism by which large phytoplankton (i.e. diatoms) exploit upwelling conditions; their initial rapid acceleration and subsequent maintenance of $\mathrm{V}_{\mathrm{NO}}$ allows large phytoplankton to dominate algal biomass in upwelling environments, as it gives them access to a disproportionate fraction of the available $\mathrm{NO}_{3}{ }^{-}$pool.

\section{C:N ratios}

Changes in the $\mathrm{C}: \mathrm{N}$ ratio of algal biomass are used as indicators of the physiological state of the assemblage, as phytoplankton have been shown to vary their elemental composition under different nutritional conditions (Goldman et al. 1979, Laws et al. 1989). The pattern observed in the total phytoplankton assemblage relative to the different size fractions implies that the $\mathrm{C}: \mathrm{N}$ ratio of the assemblage reflected that of its dominant members. Initially, the smallest size fraction dominated the phytoplankton community and controlled the total C:N ratio; by the end of the experiment, the total community ratio was most influenced by the largest size fraction.

C:N patterns similar to those discussed above were reported by Kudela \& Dugdale (2000) in 201 mesocosm experiments carried out in Monterey Bay. Kudela \& Dugdale (2000) observed phytoplankton assemblages with an initial $\mathrm{C}: \mathrm{N}$ as high as 60:1 that assimilated $\mathrm{C}$ and $\mathrm{N}$ in a ratio of $4.5: 1$. This high assimilation ratio was attributed to $\mathrm{N}$ and/or light limitation, and Kudela \& Dugdale (2000) suggested that stabilization of the phytoplankton in their enclosures promoted an immediate increase in $\mathrm{C}$ fixation due to release from light limitation. The 2001 mesocosms used in the present study were shaded to mimic surface light conditions, and were maintained well-mixed to ensure the phytoplankton inoculum experienced minimal change of light regime. It is unlikely therefore that the observed initial high $\mathrm{C}: \mathrm{N}$ ratios were a response to release from light limitation.

The initial high $\mathrm{C}: \mathrm{N}$ ratios probably indicate severe $\mathrm{N}$ limitation, which is consistent with a lack of upwelling conditions (www.pfeg.noaa.gov) and extremely low surface $\left[\mathrm{NO}_{3}{ }^{-}\right]$(K. Johnson pers. comm.) in Monterey Bay over more than 2 wk prior to the experiment. It appears from the near constant proportion $(6.3 \pm 1.2: 1)$ in which the community assimilated $\mathrm{C}$ and $\mathrm{N}$ that nutrient replete conditions ultimately led to the re-establishment of a lower $\mathrm{C}$ : $\mathrm{N}$ elemental composition and that luxury uptake of $\mathrm{N}$ did not occur. The final $\mathrm{C}: \mathrm{N}$ ratio of the total assemblage was $7-8: 1$, which is to be expected from the relatively constant, Redfield-like proportion in which $\mathrm{C}$ and $\mathrm{N}$ were assimilated. Had 
the experiment continued for another day, it is likely that the total assemblage $\mathrm{C}: \mathrm{N}$ would have reached $\sim 6.3: 1$.

In a similar mesocosm experiment, Wetz \& Wheeler (2003) found that during the exponential phase of coastal phytoplankton blooms, little dissolved organic material (DOM) was produced, and the C:N ratio of particulate organic material (POM) was approx. the Redfield-predicted value. However, once the phytoplankton depleted the available $\mathrm{NO}_{3}{ }^{-}$, DOM production increased and excess $\mathrm{C}$ fixation occurred, increasing the $\mathrm{C}: \mathrm{N}$ ratio of $\mathrm{POM}$ to $\geq 16$ (Wetz \& Wheeler 2003). The initial elevated phytoplankton C:N ratios measured in the present study may result from such excess $\mathrm{C}$ fixation during the nutrient poor conditions experienced in Monterey Bay prior to the beginning of the barrel experiment.

Other possible explanations for initially elevated $\mathrm{C}: \mathrm{N}$ ratios include the presence of a large percentage of C-rich detrital material in the inoculum or bacterial competition for inorganic N. While a pool of organic C-rich detritus can explain initially elevated biomass $\mathrm{C}: \mathrm{N}$ ratios, it cannot explain the constant $\mathrm{C}: \mathrm{N}$ assimilation ratios observed over the entire time-course. A C-rich detrital pool would be diluted by an increase in phytoplankton biomass, decreasing the $\mathrm{C}: \mathrm{N}$ ratio as observed. However, since detritus cannot assimilate nutrients, this would also result in a variable $\mathrm{C}: \mathrm{N}$ assimilation ratio, which was not observed.

GF/F filters $(\sim 0.7 \mu \mathrm{m})$ were used to capture the biomass analyzed for $\mathrm{C}$ and $\mathrm{N}$ content. Many bacteria are smaller than this filter pore size and would not have been caught on the GF/F filters (Altabet 1990). If a bacterial assemblage had consumed sufficient inorganic $\mathrm{N}$ to prevent phytoplankton obtaining enough to decrease their $\mathrm{C}: \mathrm{N}$ ratios, but were not caught on the filters, an $\mathrm{N}$ mass balance would not have been observed. Additionally, it has been shown that heterotrophic bacteria tend to be out-competed for inorganic $\mathrm{N}$ by autotrophic cells at high ambient nutrient concentrations (Suttle et al. 1990). It therefore seems unlikely that bacteria were a variable or important PN pool in the barrels.

The observed changes in C:N ratios point to the ability of phytoplankton to respond rapidly to the presence of new nutrients in their environment. Increased $\mathrm{NO}_{3}{ }^{-}$ drawdown and biomass accumulation only became apparent by Day 4 and 5 of the experiment. Nonetheless, the biomass $\mathrm{C}: \mathrm{N}$ ratio changed considerably before Day 5 as phytoplankton began to exploit changes in their environment. While the community must have been assimilating small amounts of $\mathrm{C}$ and $\mathrm{N}$ prior to Day 5, no significant resultant changes in total PN or chlorophyll* were detectable in the barrels. Thus the response time of the assemblage to upwelling is faster than it appears purely from $\mathrm{NO}_{3}{ }^{-}$drawdown and biomass or chlorophyll ${ }^{*}$ accumulation and is likely driven by the initial rapid uptake of $\mathrm{NO}_{3}{ }^{-}\left(\mathrm{V}_{\mathrm{NO} 3}\right)$ by the largest phytoplankton, detectable with isotope tracers.

\section{f-ratios}

The concept of the f-ratio was introduced by Eppley \& Peterson (1979) as a way to quantify export production from the surface ocean, estimated as production due to assimilation of newly input $\mathrm{N}$ (new production) relative to total production due to $\mathrm{N}$ uptake (new + regenerated production) (Dugdale \& Goering 1967). It is standard practice to quantify the f-ratio from $\mathrm{V}_{\mathrm{NO} 3}$ and $\mathrm{V}_{\mathrm{NH} 4}$ measured during short-term tracer experiments ( $3 \mathrm{~h}$ in this study): $\mathrm{V}_{\mathrm{NO} 3}$ is taken to represent new production, $\mathrm{V}_{\mathrm{NH} 4}$ regenerated production (provided there is no $\mathrm{N}$ fixation, atmospheric $\mathrm{N}$ deposition, DON cycling or nitrification; Bronk et al. 1994), and the f-ratio $=\mathrm{V}_{\mathrm{NO} 3} /\left(\mathrm{V}_{\mathrm{NO} 3}+\mathrm{V}_{\mathrm{NH} 4}\right)$ (Eppley \& Peterson 1979). ${ }^{15} \mathrm{~N}$ additions to such incubation experiments are typically considered 'tracer-level' if they are $\leq 10 \%$ of the ambient source concentration (Lipschultz 2008). Additions of higher concentration can result in stimulated or 'surge' transport (Goldman \& Glibert 1982, Kanda et al. 1988) and thus greater apparent rates of assimilation than would be observed in the environment at lower or ambient substrate concentrations.

In eutrophic environments such as upwelling regions, the ambient $\left[\mathrm{NO}_{3}{ }^{-}\right]$is generally sufficiently high that tracer-level incubation experiments (i.e. ${ }^{15} \mathrm{~N}-\mathrm{NO}_{3}{ }^{-}$additions $\leq 10 \%$ ambient $\left[\mathrm{NO}_{3}{ }^{-}\right]$; Lipschultz 2008) can be conducted without stimulating uptake (e.g. Probyn 1985, Dugdale \& Wilkerson 1991, Dickson \& Wheeler 1995). However, the $\left[\mathrm{NH}_{4}^{+}\right]$in such regions is typically very low, even in newly upwelled waters $(<0.02$ to $0.63 \mu \mathrm{mol}$ $\mathrm{l}^{-1}$ in Monterey Bay; Kudela \& Dugdale 2000, Dugdale et al. 2006, Wilkerson et al. 2006), so that quantifying rates of $\mathrm{NH}_{4}{ }^{+}$assimilation requires ${ }^{15} \mathrm{~N}$ additions on the order of 50 to $100 \%$ of the ambient $\left[\mathrm{NH}_{4}{ }^{+}\right]$.

For the short-term incubations carried out in the present study, ${ }^{15} \mathrm{~N}_{-} \mathrm{NO}_{3}{ }^{-}$additions were calculated on a daily basis to ensure they remained $\leq 10 \%$ of the ambient concentration. Thus, the calculated rates of $\mathrm{NO}_{3}{ }^{-}$ assimilation (both $\rho_{\mathrm{NO} 3}$ and $\mathrm{V}_{\mathrm{NO} 3}$ ) represent realistic uptake rates for the barrels. Since ambient $\left[\mathrm{NH}_{4}{ }^{+}\right]$was very low after the first day, it was necessary to incubate with significantly more than $10 \%$ of the ambient $\left[\mathrm{NH}_{4}{ }^{+}\right]$to provide sufficient substrate to detect the ${ }^{15} \mathrm{~N}$ label in the PN. The resulting transport and specific $\mathrm{NH}_{4}{ }^{+}$uptake rates are therefore indicative of the potential for phytoplankton to take up $\mathrm{NH}_{4}{ }^{+}$, and are not realistic estimates of actual $\mathrm{NH}_{4}{ }^{+}$assimilation rates in the mesocosms for most of the experiment. 
For the whole experiment, the average f-ratio in the barrels was $0.46 \pm 0.18$, similar to previous measurements from upwelling environments including Monterey Bay (Olivieri 1996, Kudela \& Dugdale 2000). However, measured phytoplankton biomass accumulation was principally due to $\mathrm{NO}_{3}{ }^{-}$assimilation, as $\mathrm{NO}_{3}{ }^{-}$was available to the assemblage at all times, whereas $\mathrm{NH}_{4}{ }^{+}$was only present during the short-term incubation experiments. Based on $\mathrm{N}$ mass balance and microscope counts indicating the presence of very few micrograzers, we conclude that grazing on large cells, and thus DON and $\mathrm{NH}_{4}{ }^{+}$recycling, was minimal. Therefore, the growth rate implied by PN accumulation and $\mathrm{CO}_{2}$ fixation $\left(\sim 1 \mathrm{~d}^{-1}\right.$; Fig. 1A) should be accurately estimated by $\mathrm{V}_{\mathrm{NO} 3}$ (rather than $\mathrm{V}_{\mathrm{NO} 3}+\mathrm{V}_{\mathrm{NH} 4}$ ) for each day of the experiment, as was observed.

We conclude that the calculated values of $\mathrm{V}_{\mathrm{NH} 4}$ used to estimate the f-ratio in the barrels resulted from the stimulation of $\mathrm{NH}_{4}{ }^{+}$uptake by the addition of an external source of $\mathrm{NH}_{4}{ }^{+}\left({ }^{15} \mathrm{~N}-\mathrm{NH}_{4}{ }^{+}\right)$during short incubation experiments. Therefore, $\mathrm{V}_{\mathrm{NH} 4}$ cannot be reliably used as a proxy for regenerated production in the barrels or in the ocean. This observation calls into question the validity of the f-ratio as a way to quantify new production in our experiment, and indeed in other experiments where $\mathrm{V}_{\mathrm{NH} 4}$ was measured under non-tracer circumstances. Under these conditions, the true f-ratio, and thus the actual reliance of production on $\mathrm{NO}_{3}{ }^{-}$, may be underestimated from short-term non-tracer incubations.

\section{Pigment distributions}

Phytoplankton pigment concentrations corroborated the findings implied by $\mathrm{PN}$ and $\mathrm{PC}$ accumulation, rates of $\mathrm{N}$ and $\mathrm{C}$ assimilation, and the increasing contribution to biomass by the larger size fraction with time. For example, by Day 8, approx. $80 \%$ of the chlorophyll* in B3 could be attributed to phytoplankton $>20 \mu \mathrm{m}$ in size, along with 60 and $80 \%$ of the total PN and $\mathrm{PC}$ biomass, respectively.

In contrast to the ubiquitous nature of chlorophyll*, fucoxanthin, the most abundant pigment after chlorophyll ${ }^{*}$, is an accessory pigment unique to only a few groups of phytoplankton, including diatoms, chrysophytes and haptophytes (Stauber \& Jeffrey 1988, Bjørnland \& Liaaen-Jensen 1989, Jeffrey 1989). Chrysophytes are predominantly freshwater organisms (Sandgren et al. 1995), and neither they nor any haptophytes were identified in the B3 assemblage by light microscopy. Fucoxanthin concentrations in B3 were highest in the $>20 \mu \mathrm{m}$ size fraction, with some contribution from the smallest phytoplankton, and we conclude that measured fucoxanthin concentrations were directly representative of the presence of diatoms. These observations were further confirmed by light microscope identification of 52 species of diatoms in B3, which made up a substantial portion of the $>20 \mu \mathrm{m}$

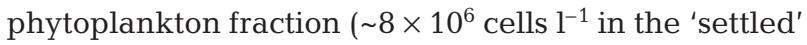
microscopy counts).

\section{Changing diatom species abundance}

Succession occurs when particular resources become available in an environment and some species replace others with different characteristics (Valiela 1984), as occurred within the diatom assemblage in B3. Initially, the diatom community was dominated by a few ubiquitous oceanic and coastal species that succeed under low nutrient conditions (e.g. Pseudonitzschia spp.), and diversity was low. As $\mathrm{NO}_{3}^{-}$became available to the assemblage, diversity increased. We conclude that this higher diversity was due to an increase in the abundance of upwelling diatom species (e.g. Chaetoceros debilis) in response to the input of $\mathrm{NO}_{3}{ }^{-}$to the system. In addition, the relative abundance of the original species declined as they were out-competed by others better able to exploit the new environmental conditions. By Day 8 , the upwelling species accounted for $~ 80 \%$ of the diatom assemblage. They responded more rapidly than other species to the input of new $\mathrm{NO}_{3}{ }^{-}$, and as a result came to completely dominate the assemblage, at which point total diversity decreased again. This sequence of changing species dominance is consistent with Margalef's theory of succession in upwelling environments (Margalef 1967).

The pattern of increasing, then decreasing diversity during a nutrient-driven bloom (Margalef 1967) was not observed in the total phytoplankton assemblage, however. Initially, diversity was low, although cell counts were sufficiently high for robust diversity estimates (data not shown), and did not increase until Day 5 despite high $\left[\mathrm{NO}_{3}{ }^{-}\right]$. By the end of the experiment, $\mathrm{NO}_{3}{ }^{-}$had declined but total assemblage diversity was still increasing, which implies either an increase in the number of species in the barrels, or an increase in the evenness of the assemblage. Results of light microscopy indicate that the relative abundance of organisms not well represented during the first days of the experiment increased significantly by Day 8, resulting in a more even community.

Central to the present study was the hypothesis that diatoms are able to respond earlier and more rapidly to the presence of $\mathrm{NO}_{3}{ }^{-}$than any other phytoplankton group, allowing them to thrive in upwelling conditions. Changing diversity of the diatom group relative to the total phytoplankton assemblage provides convincing support for this hypothesis; upwelling diatom abun- 
dance increased rapidly in response to the input of $\mathrm{NO}_{3}{ }^{-}$into a previously $\mathrm{N}$-deplete system, while the phytoplankton assemblage as a whole seemed to respond to a different parameter. This observation is further corroborated by the timescale upon which $\mathrm{NO}_{3}{ }^{-}$drawdown and biomass accumulation were observed. The phytoplankton community as a whole did not cause noticeable changes in $\left[\mathrm{NO}_{3}{ }^{-}\right]$or $\mathrm{PN}$ and PC until halfway through the experiment. By this stage, however, the diatom assemblage was already almost dominated by species specially adapted to upwelling conditions.

\section{CONCLUSIONS}

The results of all measurements reported in this study demonstrate that the mesocosm experiment successfully simulated upwelling and the early stages of a subsequent phytoplankton bloom. Both biomass and size structure of the bloom were consistent with oceanographic patterns observed in natural systems. We witnessed an initially severely N-limited phytoplankton community assimilate $\mathrm{NO}_{3}^{-}$and $\mathrm{CO}_{2}$ in a ratio that allowed return to balanced growth. $\mathrm{N}$ mass balance was maintained, with assimilated $\mathrm{NO}_{3}{ }^{-}$being incorporated quantitatively into $\mathrm{PN}$ biomass over the course of the experiment. While biomass increased as a function of time in all size fractions, the relative contribution of the largest phytoplankton increased most, as did their rates of $\mathrm{N}$ and $\mathrm{C}$ transport. The largest phytoplankton also achieved their maximum specific $\mathrm{NO}_{3}{ }^{-}$ uptake rate sooner than the other size fractions, maintaining this high rate for most of the duration of the experiment. Pigment concentrations and light microscopy pointed explicitly to diatoms as the dominant functional group in the bloom, and our microscopy counts further illuminated the rapid response of these diatoms to an input of new nutrients. High $\left[\mathrm{NO}_{3}{ }^{-}\right]$in the barrels resulted in the rapid replacement of ubiquitous diatom species with species adapted to exploit upwelling conditions, a shift that occurred before significant $\mathrm{NO}_{3}{ }^{-}$drawdown or biomass accumulation was observed, but in keeping with rapid attainment of maximum $\mathrm{V}_{\mathrm{NO} 3}$ by the large phytoplankton. The pattern of changing diatom diversity was different from that of the assemblage as a whole, suggesting diatoms responded to $\mathrm{NO}_{3}{ }^{-}$while community diversity was apparently controlled by other variables.

We conclude that diatoms came to dominate the phytoplankton biomass due to their ability to respond most rapidly to newly input $\mathrm{NO}_{3}{ }^{-}$. They increased their $\mathrm{V}_{\mathrm{NO}}$ before the rest of the assemblage, and maintained it longest, allowing for the consumption of a disproportionate fraction of the available nutrients. The observed success of diatoms in coastal upwelling regimes is thus likely due to fast, $\mathrm{NO}_{3}{ }^{-}$-supported growth of upwelling-adapted species. High growth rates allow diatoms to out-compete other phytoplankton and utilize more of the limiting nutrient in order to accumulate high levels of biomass before being grazed. That diatoms are an extremely important contributor to new production, as well as to $C$ export and sequestration, is thus due to their rapid and sustained growth on newly upwelled $\mathrm{NO}_{3}{ }^{-}$.

We found that an f-ratio calculated from ${ }^{15} \mathrm{~N}$ tracer incubation-derived $\mathrm{V}_{\mathrm{NO} 3}$ and $\mathrm{V}_{\mathrm{NH} 4}$ values was not appropriate for this experiment and probably underestimated new production in the barrels because of low ambient $\left[\mathrm{NH}_{4}{ }^{+}\right]$and artifactually high $\mathrm{NH}_{4}{ }^{+}$uptake implied by non-tracer incubations. A true measure of new and regenerated production during upwelling would be far more difficult to quantify, requiring consideration of $\mathrm{NH}_{4}{ }^{+}$and DON produced due to grazing, sloppy feeding, zooplankton excretion and cell lysis over the course of the bloom. In light of this, perhaps previous f-ratios based on $\mathrm{V}_{\mathrm{NO} 3}$ and $\mathrm{V}_{\mathrm{NH} 4}$ calculated under non-tracer conditions need to be treated with greater caution.

Acknowledgements. We thank B. Song and P. Bhadury for assistance with sample collection and incubation experiments. The staff of Moss Landing Marine Laboratory and Captain L. Bradford of the R/V 'John Martin' were most cooperative and helpful. Our grateful thanks to A. Babbin and O. Coyle for their meticulous measurement of ammonium concentrations. We acknowledge the measurement of pigment concentrations by $\mathrm{C}$. Tomas and the taxonomic identification of the phytoplankton assemblage by A. Gibson. This research was supported by a Princeton First Year Fellowship in Science and Engineering to S.E.F. and NSF grants to B.B.W.

\section{LITERATURE CITED}

Altabet MA (1990) Organic C, N, and stable isotope composition of particulate matter collected on glass-fiber and aluminum oxide filters. Limnol Oceanogr 35:902-909

Bjørnland T, Liaaen-Jensen S (1989) Distribution patterns of carotenoids in relation to chromophyte phylogeny and systematics. In: Green JC, Leadbeater BSC, Diver WL (eds) The chromophyte algae: problems and perspectives. Clarendon Press, Oxford, p 37-60

Bronk DA, Ward BB (1999) Gross and net nitrogen uptake and DON release in the euphotic zone of Monterey Bay, California. Limnol Oceanogr 44:573-585

> Bronk DA, Glibert PM, Ward BB (1994) Nitrogen uptake, dissolved organic nitrogen release, and new production. Science 265:1843-1846

Bronk DA, Lomas MW, Glibert PM, Schukert KJ, Sanderson MP (2000) Total dissolved nitrogen analysis: comparisons between the persulfate, UV and high temperature oxidation methods. Mar Chem 69:163-178

> Buck KR, Uttal-Cooke L, Pilskaln CH, Roelke DL and others (1992) Autoecology of the diatom Pseudonitzschia aus- 
tralis, a domoic acid producer, from Monterey Bay, California. Mar Ecol Prog Ser 84:293-302

Chavez FP (1996) Forcing and biological impact of onset of the 1992 El Niño in central California. Geophys Res Lett 23:265-268

Chavez FP, Smith LE (1995) Biological and chemical consequences of open ocean upwelling. In: Summerhayes CP, Emeis KC, Angel MV, Smith RL, Zeitschel B (eds) Upwelling in the oceans: modern processes and ancient records. Wiley, New York, NY, p 149-171

Chavez FP, Barber RT, Kosro M, Huyer A, Ramp S, Stanton TP, Rojas de Mendiola B (1991) Horizontal transport and the distribution of nutrients in the coastal transition zone off northern California - effects on primary production, phytoplankton biomss and species composition. J Geophys Res 96:14833-14848

> Dickson ML, Wheeler PA (1995) Nitrate uptake rates in a coastal upwelling regime-a comparison of PN-specific, absolute, and chlorophyll a-specific rates. Limnol Oceanogr 40:533-543

- Dortch Q (1990) The interaction between ammonium and nitrate uptake in phytoplankton. Mar Ecol Prog Ser 61: 183-201

Dugdale RC (1985) The effects of varying nutrient concentration on biological production in upwelling regions CalCOFI Report 26:93-96

> Dugdale RC, Goering JJ (1967) Uptake of new and regenerated forms of nitrogen in primary production. Limnol Oceanogr 12:196-206

> Dugdale RC, Wilkerson FP (1991) Low specific nitrate uptake rate: a common feature of high-nutrient, low-chlorophyll marine ecosystems. Limnol Oceanogr 36:1678-1689

Dugdale RC, Wilkerson FP, Marchi A, Hogue VE (2006) Nutrient controls on new production in the Bodega Bay, California, coastal upwelling plume. Deep-Sea Res II 53: 3049-3062

- Eppley RW, Peterson BJ (1979) Particulate organic matter flux and planktonic new production in the deep ocean. Nature 282:677-680

Garrison DL, Gibson A, Coale SL, Gowing MM, Okolodkov YB, Fritsen CH, Jeffries MO (2005) Sea-ice microbial communities in the Ross Sea: autumn and summer biota. Mar Ecol Prog Ser 300:39-52

- Garside C (1982) A chemiluminescent technique for the determination of nanomolar concentrations of nitrate and nitrite in seawater. Mar Chem 11:159-167

Goericke R (2002) Top-down control of phytoplankton biomass and community structure in the monsoonal Arabian Sea. Limnol Oceanogr 47:1307-1323

Goldman JC, Glibert PM (1982) Comparative rapid ammonium uptake by 4 species of marine phytoplankton. Limnol Oceanogr 27:814-827

Goldman JC, McCarthy JJ, Peavey DG (1979) Growth rate influence on the chemical composition of phytoplankton in oceanic waters. Nature 279:210-215

> Hofmann E, Wrench PM, Sharples FP, Hiller RG, Welte W, Diederichs K (1996) Structural basis of light harvesting by carotenoids: peridinin-chlorophyll-protein from Amphidinium carterae. Science 272:1788-1791

Huisman J, Sommeijer B (2002) Maximal sustainable sinking velocity of phytoplankton. Mar Ecol Prog Ser 244:39-48

Irigoien X, Huisman J, Harris RP (2004) Global biodiversity patterns of marine phytoplankton and zooplankton. Nature 429:863-867

Jeffrey SW (1989) Chlorophyll a pigments and their distribution in the chromophyte algae In: Green JC, Leadbeater BSC, Diver WL (eds) The chromophyte algae: problems and perspective. Systematics Association Special Vol 38. Clarendon Press, Oxford, p 13-36

Jeffrey SW, Hallegraeff GM (1987) Chlorophyllase distribution in ten classes of phytoplankton: a problem for chlorophyll analysis. Mar Ecol Prog Ser 35:293-304

Jickells TD (1998) Nutrient biogeochemistry of the coastal zone. Science 281:217-222

Joint I, Hendriksen P, Fonnes GA, Bourne D, Thingstad TF, Riemann B (2002) Competition for inorganic nutrients between phytoplankton and bacterioplankton in nutrient manipulated mesocosms. Aquat Microb Ecol 29:145-159

Kanda J, Saino T, Hattori A (1988) Ammonium uptake and synthesis of cellular nitrogenous macromolecules in phytoplankton. Limnol Oceanogr 33:1568-1579

Koroleff F (1983) Determination of ammonia. In: Grasshoff K, Ehrhardt M, Kremling K (eds) Methods of seawater analysis. Verlag Chemie, Weinheim, p 150-157

Kudela RM, Dugdale RC (1996) Estimation of new production from remotely-sensed data in a coastal upwelling regime. Adv Space Res 18:91-97

Kudela RM, Dugdale RC (2000) Nutrient regulation of phytoplankton productivity in Monterey Bay, California. DeepSea Res II 47:1023-1053

Laws EA, DiTullio GR, Betzer PB, Karl DM, Carder KL (1989) Autotropic production and elemental fluxes at $26^{\circ} \mathrm{N}$, $155^{\circ} \mathrm{W}$ in the North Pacific central gyre. Deep-Sea Res 36:103-120

Lipschultz F (2008) Isotope tracer methods for studies of the marine nitrogen cycle. In: Capone DG, Bronk DA, Mulholland MR, Carpenter EJ (eds) Nitrogen in the marine environment. Elsevier, p 1345-1384

Malone TC (1980) Size-fractionated primary productivity of marine phytoplankton. In: Falkowski PG (ed) Primary productivity in the sea. Plenum Press, New York, NY, p 301-319

- Margalef R (1967) The food web in the pelagic environment. Helgol Wiss Meeresunters 15:548-559

Nelson DM, Tréguer P, Brzezinski MA, Leynaert A, Quéguiner B (1995) Production and dissolution of biogenic silica in the ocean: Revised global estimates, comparison with regional data and relationship to biogenic sedimentation. Global Biogeochem Cycles 9:359-372

Oksanen J, Kindt R, Legendre P, O'Hara B, Simpson GL, Stevens MHH (2008) Vegan: community ecology package. $\mathrm{R}$ package version 1.11-4. R: A language and environment for statistical computing. R Foundation for Statistical Computing, Vienna

Olivieri RA (1996) Phytoplankton dynamics and the fate of primary production in the coastal upwelling ecosystem of Monterey Bay, California. PhD thesis, University of California Santa Cruz

> Owens NJP, Priddle J, Whitehouse MJ (1991) Variations in nitrogen assimilation around South Georgia and in the Bransfield Strait (Southern Ocean). Mar Chem 35:287-304

> Probyn TA (1985) Nitrogen uptake by size-fractionated phytoplankton populations in the southern Benguela upwelling system. Mar Ecol Prog Ser 22:249-258

Probyn TA (1992) The inorganic nutrition of phytoplankton in the Southern Benguela: new production, phytoplankton size and implications for foodwebs. S Afr J Mar Sci 12:411-420

Redfield AC, Ketchum BH, Richards FA (1963) The influence of organisms on the composition of water. In: Hill MN (ed) The Sea, Vol 2. Wiley, New York, NY, p 26-77

Round FE, Crawford RM, Mann DG (1990) The diatoms: biology and morphology of the genera. Cambridge University Press, Cambridge 
Rykaczewski RR, Checkley DM Jr (2008) Influence of ocean winds on the pelagic ecosystem in upwelling regions. Proc Natl Acad Sci USA 105:1965-1970

Samuelsson K, Berglund J, Haecky P, Andersson A (2002) Structural changes in an aquatic microbial food web caused by inorganic nutrient addition. Aquat Microb Ecol 29:29-38

Sandgren CD, Smol JP, Kristiansen PJ (eds) (1995) Chrysophyte algae: ecology, phylogeny and development. Cambridge University Press, Cambridge, NY

Stauber JL, Jeffrey SW (1988) Photosynthetic pigments in fifty-one species of marine diatoms. J Phycol 24:158-172

Stehr M, Connell L, Baugh KA, Bill BD, Adams NG, Trainer VL (2002) Morphological, toxicological, and genetic differences among Pseudo-nitzschia (Bacillariophyceae) species in inland embayments and outer coastal waters of Washington State, USA. J Phycol 38:55-65

Stolte W, Riegman R (1995) Effect of phytoplankton cell size on transient-state nitrate and ammonium uptake kinetics. Microbiology 141:1221-1229

Strickland JDH, Parsons TR (1968) A practical handbook of seawater analysis. Fish Res Board Can, Bull 167, Ottawa

Suttle CA, Fuhrman JA, Capone DG (1990) Rapid ammonium cycling and concentration-dependent partitioning of ammonium and phosphate: implications for carbon transfer in planktonic communities. Limnol Oceanogr 35: 424-432

Tamigneaux E, Vazquez E, Mingelbier M, Klein B, Legendre L (1995) Environmental control of phytoplankton assemblages in nearshore marine waters, with special emphasis on phototrophic ultraplankton. J Plankton Res 17:1421-1447

Toon RK, Lohrenz SE, Rathbun CE, Wood AM and others (2000) Photosynthesis-irradiance parameters and community structure associated with coastal filaments and adjacent waters in the northern Arabian Sea. Deep-Sea Res II 47:1249-1277

Valiela I (1984) Marine ecological processes. Springer-Verlag, New York, NY

Editorial responsibility: Hans Heinrich Janssen, Oldendorf/Luhe, Germany
Varela M, Del Rio G, Alvarez-Ossorio MT, Costas E (1991) Factors controlling phytoplankton size class distribution in the upwelling area of the Galician continental shelf (NW Spain). Sci Mar 55:505-518

Vidussi F, Claustre H, Bustillos-Guzman J, Cailliau C, Marty JC (1996) Determination of chlorophylls and carotenoids of marine phytoplankton: separation of chlorophyll a from divinyl-chlorophyll $a$ and zeaxanthin from lutein. J Plankton Res 18:2377-2382

Volk T, Hoffert MI (1985) Ocean carbon pumps: analysis of relative strengths and efficiencies on ocean-atmospheric $\mathrm{pCO}_{2}$ changes. In: Sundquist ET, Broecker WS (eds) The carbon cycle and atmospheric $\mathrm{CO}_{2}$, natural variation, Vol 32. American Geophysical Union, Washington, DC, p 99-120

> Ward BB, Bronk DA (2001) Net nitrogen uptake and DON release in surface waters: importance of trophic interactions implied from size fractionation experiments. Mar Ecol Prog Ser 219:11-24

- Wetz MS, Wheeler PA (2003) Production and partitioning of organic matter during simulated phytoplankton blooms. Limnol Oceanogr 48:1808-1817

- Wilkerson FP, Dugdale RC, Barber RT (1987) Effects of El Niño on new, regenerated and total production in eastern boundary upwelling systems. J Geophys Res 92: $14347-14353$

> Wilkerson FP, Dugdale RC, Kudela RM, Chavez FP (2000) Biomass and productivity in Monterey Bay, California: contribution of the large phytoplankton. Deep-Sea Res II 47:1003-1022

Wilkerson FP, Dugdale RC, Marchi A, Hogue VE, Lassiter AM (2006) The phytoplankton bloom response to wind events and upwelled nutrients during the CoOP-WEST study. Deep-Sea Res II 53:3023-3048

Wright SW, Jeffrey SW, Mantoura RFC, Llewellyn CA, Bjørnland T, Repeta D, Welschmeyer N (1991) Improved HPLC method for analysis of chlorophylls and carotenoids from marine phytoplankton. Mar Ecol Prog Ser 77: 183-196

Submitted: April 23, 2010; Accepted: February 1, 2011 Proofs received from author(s): April 18, 2011 